\title{
FEDERALISM AND FOREIGN RELATIONS
}

If we are to be one nation in any respect, it clearly ought to be in respect to other nations. $\dagger$

JOHN NORTON MOORE*

I

\section{INTRODUCTION}

$\mathrm{D}$ URING recent years, the United States and most of the other nations of the world have become increasingly concerned with the course of international affairs. ${ }^{1}$ The demands of this era have increased the need for centralized effectuation of foreign policy and for a more realistic redefinition of foreign relations designed to consider the often sophisticated and pervasive effect of domestic policy on the international scene. As is abundantly evident in The Federalist Papers, one of the principal purposes of the union upon which our nation is based was to achieve centralized control over the foreign relations of the individual states. ${ }^{2}$ The Constitution of the United States reflects this purpose by providing various techniques for achieving the centralization of foreign relations. ${ }^{3}$ Thus, in com. menting on the foreign relations power left to the states under the Constitution, the Supreme Court was able to declare in the famous cases of United States $v$. Belmont ${ }^{4}$ and United States $v$. Pink:5

In respect of all international negotiations and compacts, and in respect of our foreign relations generally, state lines disappear. As to such purposes the State of New York does not exist. ${ }^{B}$

† The Federalist No. 42, at 259 (Lodge ed. 1923) (Madison).

- B.A. 1959, Drew University; LL.B. 1962, Duke University; LL.M. 1965, University of Illinois. Assistant Dean and Assistant Professor of Law, University of Florida. This article is based on a thesis submitted in partial fulfillment of the requirements for the degree of Master of Laws at the University of Illinois.

${ }^{1}$ See Almond, The American People and Foreign Policy 3 (1950).

2 See The Federalist Nos. 3, 4, 5, 22, 42, 80. "The importance of national power in all matters relating to foreign affairs and the inherent danger of state action in this field are clearly developed in Federalist papers No. 3, 4, 5, 42 and 80." Hines v. Davidowitz, 312 U.S. 52, $62 \mathrm{n.9}$ (1941). See generally WARREN, The Making of the Constitution (1937).

${ }^{3}$ U.S. Const. art. I, § 8, cls. 3, 10; art. I, § 10, cls. 1, 3; art. II, §§ 2, 3; art. 1II, § 2; art. VI, cl. 2.

- 301 U.S. 324 (1937).

- 315 U.S. 203 (1942).

- 301 L.S. at 331. 
We repeat that there are limitations on the sovereignty of the States. No State can rewrite our foreign policy to conform to its own domestic policies. Power over external affairs is not shared by the States; it is vested in the national government exclusively. ${ }^{7}$

Despite these and other similarly sweeping asseverations, there exist today important areas of uncertainty regarding the relationship between state policies and the national foreign relations power. The heated debates over the so-called Bricker Amendment, involving a proposal to increase state control over the treaty and congressionalexecutive powers, have provided one of the few recent excursions into these uncertainties. ${ }^{8}$ The context of these debates, however, has done little to expose other perhaps equally important problems in insuring federal control of foreign relations. In fact, by emphasizing nonexistent, bright-line distinctions between "domestic" and "foreign" affairs, the proponents in these debates may have discouraged realistic appraisal of other areas of uncertainty.

One such area in need of clarification is a product of the dual nature of our state-federal court system. Although state courts handle many cases involving international law and foreign relations, ${ }^{9}$ it has been uncertain to what extent they are bound by federal court determination of these issues, ${ }^{10}$ or even whether the Supreme Court has sufficient review power over state court decisions to assure federal dominance at all on these questions. ${ }^{11}$ Moreover, it was un-

7315 U.S. at 233.

- See Hatch, Finch \& Ober, The Treaty Power and the Constitution: The Case for Amendment, 40 A.B.A.J. 207 (1954); MacChesney, McDougal, Mathews, Oliver \&: Ribble, The Treaty Power and the Constitution: The Case Against Amendment, 40 A.B.A.J. 203 (1954).

- See, e.g., Confederation Life Ass'n v. Ugalde, 164 So. 2d 1 (Fla. 1964); Johnston v. Compagnie Générale Transatlantique, 242 N.Y. 381, 152 N.E. 121 (1926); Russian Reins. Co. v. Stoddard, 240 N.Y. 149, 147 N.E. 703 (1925); Stephen v. Zivnostenska Banka, 15 App. Div. 2d 111, 222 N.Y.S.2d 128 (Sup. Ct. 1961); Westchester County v. Ranollo, 187 Misc. 777, 67 N.Y.S.2d 31 (New Rochelle City Ct. 1946).

${ }^{10}$ See Johnston v. Compagnie Générale Transatlantique, supra note 9.

11 "But suppose a state court expressly rejects the Act of State doctrine. Here, in my opinion, Klaxon fails. Under 28 U.S.C. $\$ 1257$, there will be no certiorari from the decision of the state court of last resort, because there is no violation of the Constitution, a federal statute, or a treaty." Baade, The Legal Effect of Cuban Expropriations in the United States, 1963 Duke L.J. 290, 301. See Note, International Law-Diplomatic Immunity-Applicability of the Rule of Erie R. Co. v. Tompkins to International Law, 33 MinN. L. Rev. 540, 543-44 (1949); cf. Kurland, The Romero Case and Some Problems of Federal Jurisdiction, 73 HARv. L. REv. 817, 824 n.36 (1960). "Review of state-court judgments on certiorari is authorized 'where any title, right, or privilege or immunity is specially set up or claimed under the Constitution, treaties or statutes of, or commis. sion held or authority exercised under, the United States.' 28 U.S.C. \$ 1257 (3) (1958). (Emphasis added.) The admirality cases coming to the Supreme Court on certiorari 
certain, at least until the recent decision in Banco Nacional de Cuba v. Sabbatino, ${ }^{12}$ whether the rule of Erie R.R. v. Tompkins ${ }^{13}$ required the federal courts themselves to follow all state court determinations on questions of international law or foreign relations. ${ }^{14}$ These uncertainties, of course, pose the threat of intolerable balkanization of United States judicial participation in foreign affairs. Clarification is also needed regarding the jurisdiction of the state and federal courts to deal with questions involving international law and foreign relations, particularly with reference to whether such questions should be cognizable in the federal district courts under the general federal question jurisdiction. ${ }^{15}$

That these problems have generally not been adverted to is, perhaps, largely due to the lack of appreciation of the role of the domestic judiciary in the creation of international law and the conduct of foreign affairs. Although many questions of international law and foreign relations are ultimately determined by the executive and legislative branches, in the first instance at least, they often are decided by the judiciary. To the extent, then, that state courts decide these questions for the nation, they are in a very real sense asserting power to declare the foreign policy of the United States. Such regional determinations, with the possibility of fifty divergent viewpoints, could obviously have an embarrassing and even disastrous effect on the international relations of the United States.

Another area vitally in need of clarification as to the relationship between state policies and the national foreign relations power is the

are often based on non-statutory claims. See, e.g., Garrett v. Moore-McCormack Co., 317 U.S. 239 (1942). Nothing in $\S 1257$ (3), says Judge Magruder, would seem to authorize such review unless it be the word 'Constitution' since the word 'statute'-not 'laws'-can hardly be defined to mean judicial decisions. It is more likely that the Court's attention was not called to this defect in its certiorari jurisdiction-or that the Court chose to ignore it-than that it was sustaining jurisdiction on the ground that the cases were constitutional ones." Ibid.

12376 U.S. 398 (1964).

${ }^{18} 304$ U.S. 64 (1938). See generally Friendly, In Praise of Erie-And of the New Federal Common Law, 39 N.Y.U.L. REv. 383 (1964).

Is See Banco Nacional de Cuba v. Sabbatino, 307 F.2d 845, 869 n.16 (2d Cir. 1962), rev'd, 376 U.S. 398 (1964); Bergman v. De Sieyes, 170 F.2d 360 (2d Cir. 1948), 33 MiNN. L. REv. 540 (1949); Jessup, The Doctrine of Erie Railroad v. Tompkins Applied to International Law, 33 AM. J. INT'L L. 740 (1939).

I6 This problem has received attention in the admiralty context, but to the best of my knowledge it has never been raised with respect to international law and foreign relations questions. For the admiralty parallel see Romero v. International Terminal Operating Co., 358 U.S. 354 (1959); B. Currie, The Silver Oar and All That: A Study of the Romero Case, 27 U. CHI. L. REv. 1 (1959); Kurland, supra note 11. 
extent to which the states may affect foreign relations by the exercise of their domestic police power. Although it is fairly clear that the states cannot independently enter into treaties with foreign nations or otherwise take direct action with the declared purpose of affecting foreign relations, ${ }^{16}$ it is uncertain to what extent they can write their sometimes parochial political predilictions into the foreign policy of the United States simply by the exercise of their police power. That such state exercises of the police power, be they good or bad, can have dramatic effects on our foreign relations is evidenced by the international repercussions which resulted from the recent prosecution of a group of Cuban fishermen in the state courts of Florida ${ }^{17}$ under the newly enacted Florida Territorial Waters Act. ${ }^{18}$ Although there are certainly problems in detecting and exposing individual state action taken on the basis of foreign relations and in balancing any legitimate state interests against the possible adverse effects on our national foreign policy, such state laws should at least be scrutinized with care in order to insure that our national interest is not being needlessly jeopardized. Certainly the reasonable expectations of the other nations of the world are that the United States will conduct its foreign relations with but one voice, and in an era in which we seek to take the lead in promoting world peace through law, perhaps this is the least which can be expected.

II

\section{The Techniques of. Federal Control of Foreign Relations}

The treaty and executive agreement powers, the legislative powers of Congress, and the executive suggestion are well-recognized techniques by which the federal government can secure almost unquestioned dominance over state policies affecting national foreign relations. To some extent, however, they may be inadequate to assure federal dominance in the absence of a judicially created federal common law of foreign relations binding on the state courts.

\footnotetext{
${ }^{10}$ See U.S. ConsT. art. I, § 10; Holmes v. Jennison, 39 U.S. (14 Pet.) 540 (1840).

${ }^{17}$ State v. Manuel Gomez Barios, Criminal Nos. 416-19, Criminal Court of Record, Monroe County, Florida, January Term 1964, 3 INT'L LEg. MAT. 317 (1964). For a running sample of the publicity received by this incident see N.Y. Times, Feb. 3-13, 1964; U.S. Informs U.N. Security Council on Cuban Fishing Boat Incident, 50 DEP'T State Bull. 279 (Feb. 24, 1964). For a discussion of this incident, see part $V$ of this article.
}

${ }^{18}$ FLA. STAT. $\$ 370.21$ (1963). 
The Constitution provides that "all treaties made, or which shall be made, under the authority of the United States, shall be the supreme law of the land...."19 At least since the decision of Ware v. Hylton ${ }^{20}$ by the Supreme Court in 1796, it has been clear that state policies must yield to a valid exercise of the fcderal treaty power. Moreover, the Ware case, subsequently joined by Missouri v. Holland, ${ }^{21}$ demonstrated that the treaty power is to be construed broadly, so that almost any subject having an effect on foreign relations may be the basis of a valid treaty as long as the provisions of the treaty do not infringe any of the specific guarantees of the Constitution. ${ }^{22}$ With the possible threat of a Bricker Amendment:"3 aside, this remains the law today, although how far the trcaty power will ultimately be extended is as yet uncertain. ${ }^{24}$ In any event, it would seem that the treaty power is as broad as most of the exigencies

10 U.S. Const, art. VI, cl. 2.

${ }^{20} 3$ U.S. (3 Dall.) 199 (1796). For a recent decision reaffirming that state policies must yield to a valid exercise of the treaty power, see Kolovrat v. Oregon, 366 U.S. 187 (1961).

21252 U.S. 416 (1920).

22 See Restatement, Foreicn Relations Lay of the United States \$ 120, comment $b$ (Proposed Official Draft, 1962). "An International agreement of the United States must relate to the external concerns of the nation as distinguished from matters of a purely internal nature. As the effect of international agreements is the creation or modification of relationships under international law, it would be inconsistent to utilize them for the regulation of matters bearing no relation to international affairs. What is of international concern and appropriate for inclusion in an international agreement need not be purely of that nature since foreign relations do not fall into completely separate categories of international and domestic matters. Usually, matters of international concern have both international and domestic effects, but the existence of the latter effect in connection with the former does not remove the mattcr from international concern. However, to be of international concern, the matter must not be wholly domestic." Ibid. But a treaty or executive agreement is nevertheless subject to the spccific guarantees of the Constitution. "[N]o agreement with a foreign nation can confer power on the Congress, or on any other branch of Government, which is free from the restraints of the Constitution." Reid v. Covert, 354 U.S. 1, 16 (1957). Also see Geofroy v. Riggs, 133 U.S. 258, 267 (1890); The Cherokee Tobacco, 78 U.S. (11 Wall.) 616, 620-21 (1870). There is also a question, of course, as to whether a particular treaty is self-executing for purposes of domestic enforcement.

${ }^{28}$ See authorities cited note 8 supra. For later proposals, see BARRETT, Bruton \&: Honnold, Cases on Constitutional Law 273-74 (2d ed. 1963).

" Since questions of the treaty power and state-federal relations have been explored at length elsewhere, this paper will not consider the scope of the treaty power, but the reader should be forewarned that this is an integral part of the same overall problem and one which bears a striking parallel to the problems raised by this paper. See generally Chafce, Federal and State Powers Under the UN Covenant on Fuman Rights (pts. 1-2), 1951 W1s. L. REv. 389, 628; Henkin, The Treaty Makers and the Law Makers: The Law of the Land and Foreign Relations, 107 U. PA. L. REv. 903 (1959); McLaughlin, The Scope of the Treaty Power in the United States (pt. 1), 42 Minn. L. Rev. 709 (1958); McLaughlin, The Scope of the Treaty Power in the United States (pt. 2), 43 MiNN. L. REv. 651 (1959). 
of foreign relations would require. Moreover, pursuant to its constitutional authority to make regulations and exceptions to the appellate jurisdiction of the Supreme Court, Congress has specifically provided that the Court may review decisions concerning treaty matters from both the federal and state courts. ${ }^{25}$ Thus, between the broad treaty power and the assured right of the Supreme Court to review decisions involving such agreements, there is little doubt but that the treaty power provides an effective means of federal control over most state policies affecting foreign relations. In addition, United States $v$. Belmont ${ }^{26}$ and United States v. Pink ${ }^{27}$ point out that although not specifically authorized by the Constitution, an executive agreement is to be treated as substantially similar to a treaty. ${ }^{28}$

In several respects, however, even the treaty and congressionalexecutive, or presidential agreement, ${ }^{29}$ powers may be inadequate to achieve a unified foreign policy. Many questions affecting foreign relations are first presented in the courts, both state and federal. Questions of foreign policy and of public and private international law are not infrequently decided in the course of the day-to-day operation of the domestic judicial process, and, in fact, judicial decisionmaking may constitute a significant part of their development. ${ }^{30}$ For instance, problems relating to sovereigu immunity, the act of state doctrine, recognition of foreign judgments and a host of other areas affecting foreign relations are likely to arise and be resolved initially in the courts. Until the particular problem is adverted to nationally and the political process has culminated in a treaty or executive agreement, the judicial determination remains as the foreigu policy of the United States, the treaty power notwithstanding. The treaty and the executive agreement powers, then, may be largely ineffective in controlling, in the first instance at least, state decisions affecting

\footnotetext{
${ }^{25} 28$ U.S.C. $\S \S 1254,1257$ (1958).

20301 U.S. 324 (1937).

27315 U.S. 203 (1942).

28 See McClure, International Executive Agreements (1941); McDougal \& Lans, Treaties and Congressional-Executive or Presidential Agreements: Interchangeable Instruments of National Policy (pts. 1-2), 54 YALE L.J. 181, 534 (1945). But see Borchard, Treaties and Executive Agreements-A Reply, 54 YAIE L.J. 616 (1945).

${ }^{20}$ For an exploration of this more precise terminology, see McDougal \& Lans, supra note 28.

${ }^{30}$ See Dickinson, The Law of Nations As Part of the National Law of the United States (pts. 1-2), 101 U. PA. L. REv. 26, 792 (1952-1953). See generally Falk, The Role of Domestic Courts in the International Legal Order (1964).
} 
national foreign relations. Moreover, because of the political and other difficulties inherent in the treaty and executive agreement powers and the tendency to limit these techniques to only a few internationally recognized problems, the probability is that many not so dramatic yet quite important foreign relations questions will never be dealt with by treaty or executive agreement. In addition, it is probably not preferable to handle all of the problems which arise in these areas by resort to the treaty or executive agreement powers, since at least in some areas affecting foreign relations the judicial process may be uniquely suited for the task of international legal development. ${ }^{3 x}$

Another limitation on the treaty power as an instrument of federal control of foreign relations is the fact that when state courts make initial, independent determinations on foreign relations questions, the very position taken by them may effectively deter a treaty or executive agreement by undermining our international bargaining position. For example, in 1895 the Supreme Court held in the now ravaged case of Hilton $v$. Guyot ${ }^{32}$ that with certain exceptions the judgments of a foreign country will not be given conclusive effect when sued upon in this country unless the country in which they were rendered grants reciprocal effect to United States judgments. Unquestionably, the problem of recognition of foreign judgments is a proper subject for a treaty or executive agreement, and, in fact, many countries have solved this problem by treaty. ${ }^{33}$ Because of disagreement with the policy of the Hilton case, however, some state courts, without giving sufficient thought to their duty to follow the Supreme Court on such a question, rejected the Hilton

${ }^{31}$ See Falk, The Complexity of Sabbatino, 58 Axr. J. INT'L L. 935 (1964); Falk, Toward a Theory of the Participation of Domestic Courts in the International Legal Order: A Critique of Banco Nacional De Cuba v. Sabbatino, 16 RUTGERS L. REV. 1 (1961); Jessup, Has the Supreme Court Abdicated One of its Functions?, 40 AM. J. INT'L L. 168 (1946). See generally FALK, op. cit. supra note 30.

${ }^{32} 159$ U.S. 113 (1895).

ss "The most certain guide, no doubt, for the decision of such questions is a treaty or a statute of this country." Id. at 163 . "The countries with the non-recognition rule or the reciprocity requirement have long ceased to apply the rule generally. Through treaties or administrative determinations, judgments from numerous countries have been excepted. Scores of bilateral treaties, and some multilateral, on recoguition and enforcement of foreign judgments exist. In this hemisphere, the Montevideo Treaty of 1889 and the Bustamante Code of Private International Law cover the subject." Nadelmann, Non-Recognition of American Money Judgments Abroad and What to Do About It, 42 Iows L. REv. 236, 256 (1957). Also see Smith, The Enforcement of Foreign Judgments in American Courts, Military L. Rev., Jan 1963, p. 1. 
position and adopted their own rule. ${ }^{34}$ Regardless of the merits of the Hilton solution, the result is that there is now no uniform United States position on recognition of foreign judgments; instead there is a hodgepodge of conflicting state and federal positions.

As might be expected in a case where the states have assumed power to affect national foreign relations, independent state action in this area has had only a marginal effect in achieving the goals sought. In fact most of the nations which recognized foreign judgments on a reciprocal basis at the time of Hilton still do not list the United States as recognizing their judgments, despite subsequent state positions to the contrary. ${ }^{35}$ In addition to being largely ineffective, the independence asserted by the states in this area has to some extent undermined the international bargaining power of the United States with respect to this problem. Since some of our largest states with the greatest amounts of foreign commerce have rejected the Hilton reciprocity rule, ${ }^{36}$ other reciprocity rule and even non-enforcement rule nations have many of their judgments enforced in this country without the necessity of a treaty. The result, then, is that judgments of other nations are largely enforced in this country, while our judgments are not enforced in foreign courts.

Although this impairment of the treaty power by divergent state and federal positions may not ultimately prove crippling in dealing with this particular problem, it may adversely affect our efforts in dealing with some subsequent problem. Toleration of independent state positions on such questions may also subtly deter exercise of the treaty power by rendering the executive department reluctant to tread on alleged states rights. ${ }^{37}$ Thus, as a practical matter the

"Most notably the New York Court of Appeals in Johnston v. Compagnie Générale Transatlantique, 242 N.Y. 381, 152 N.E. 121 (1926). Also see Bonfils v. Gillespie, 25 Colo. App. 496, 139 Pac. 1054 (1914) (dictum); Coulborn v. Joseph, 195 Ga. 723, 25 S.E.2d 576 (1943). California has adopted a conclusive effect rule by statute. CAL. Crv. Proc. Code $\S 1915$. Contra, Traders' Trust Co. v. Davidson, 146 Minn. 224, 178 N.W. 735 (1920); Banco Minero v. Ross, 106 Tex. 522, 138 S.W. 224 (1911). For a general development of the American law of foreign judgments, see Smith, supra note 33 , at 7-16.

${ }^{35}$ See Nadelmann, supra note 33, at 251-53; Nadelmann, Reprisals Against American Judgments?, 65 HARv. L. REv. 1184 (1952); Note, The Enforceability of Foreign Judg. ments in American Courts, 37 NOTRE DAME LAw. 88, 96 (1961).

${ }^{86}$ For example California and New York. See authorities cited note 34 supra.

"Secretary of State Hamilton Fish on at least two occasions declined invitations for the United States to participate in international conferences on the enforcement of foreign judgments, apparently at least partly because of supposed insurmountable federalism diffculties. See Nadelmann, Ignored State Interests: The Federal Government and International Efforts to Unify Rules of Private Law, 102 U. PA. L. REv. 323, 
treaty and executive agreement powers do not always constitute an adequate technique for federal control of foreign relations.

Another technique for achieving federal control over matters affecting foreign relations is the power of Congress to enact national legislation pursuant to its article one powers, the treaty power, and any inherent foreign relations power it possesses. When Congress acts pursuant to these powers, Hines v. Davidowit $z^{38}$ and Missouri $v$. Holland $^{39}$ make it clear that state policies must yield to the resulting federal legislation, and there is no question but that the Supreme Court has adequate review power over both state and federal court decisions concerning acts of Congress. ${ }^{40}$

As is the case with the treaty and executive agreement powers, however, these legislative powers do not provide adequate federal control over foreign relations questions, since such questions frequently arise initially in the state courts where some decision must be reached. In the absence of a clear federal common law of foreign relations binding on the state courts and adequate review power, then, until Congress acts, the independent decision of a state court may determine United States foreign policy or the United States' position on a question of international law. Since it is virtually impossible for Congress to anticipate and take action on many of these questions in advance, the courts will probably remain significant decision-makers in these areas. Moreover, congressional legislation as a source of federal control of foreign relations has suffered from a generally myopic view of congressional power in this area. Doubt as to the existence of other than specifically delegated congressional powers with respect to foreign relations, coupled with meaningless classification of problems as "internal" rather than "external," and perhaps even doubt as to the proper role of Congress vis-à-vis the executive and judicial branches in the conduct of foreign affairs, has created confusion tending to confine congressional power over problems affecting foreign relations to unrealistically narrow limits. Many of these doubts as to congressional power have per-

323-27 (1954). Other examples discussed in this article bear out the reluctance of the executive branch to appear to tread on states rights in carrying out foreign relations. While recognizing that Professor Nadelmann has been a leader in calling for solution to the enforcement of foreign judgments problem, I cannot agree with his suggestion that solution requires participation of the individual states. Id. at 361-62.

${ }^{88} 312$ U.S. 52 (1941).

80252 U.S. $416(1920)$.

428 U.S.C. $\$ \S 1254,1257$ (1958). 
sisted, even though they no longer seem constitutionally justified. In fact, United States v. Curtiss-Wright Export Corp., 41 Penhallow $\boldsymbol{v}$. Doane, ${ }^{42}$ and Chief Justice Taney's opinion in Holmes $v$. Jenni$s n^{43}$ all emphasized either that power over foreign relations is conferred on the federal government by the Constitution as a whole, or that it is inherent in the federal government as the nation's sole representative in foreign affairs. It would seem, then, that congressional power over foreign relations need not be narrowly confined to specifically delegated powers. The Missouri $v$. Holland $d^{44}$ doctrine of congressional power in the implementation of treaties would lend some support to this view.

If this broader approach to the congressional foreign relations power were freely accepted and coupled with a realistic appraisal of the effect which many of the problems traditionally classified as "internal" or "domestic" have on foreign relations, congressional power to legislate in the area of foreign relations could be greatly expanded to better conform to the realities of a world which refuses to draw lines at national boundaries. ${ }^{45}$ To some extent, perhaps, congressional power as a source of federal control over foreign relations could also be strengthened by liberal judicial findings to the effect that Congress has, by silence or otherwise, preempted particular areas in the field of foreign relations. ${ }^{46}$ Although such a rationale might provide a plausible constitutional basis for decision, it would still largely reflect simply judicial determinations that certain problems require national treatment, and such determinations would closely approximate a federal common law of foreign relations.

In any event, the fact remains that as a practical matter Congress

\footnotetext{
11299 U.S. 304 (1936).

123 U.S. (3 Dall.) 54 (1795).

4239 U.S. (14 Pet.) 540 (1840).

“ 252 U.S. 416 (1920).

"t If you feel that the arguments presented in favor of broad congressional authority in the area of foreign relations somewhat stretch a point, it might be helpful to recall that one source of congressional power in admiralty is implication from the article III grant of judicial power in admiralty cases. See Panama R.R. v. Johnson, 264 U.S. 375 (1924); Gilmore \& BLACK, THE LAw OF Admiralty 42 (1957). In fact, although the additional argument is perhaps superfluous, if article III as a whole grants judicial power over foreign relations causes as such, why shouldn't the admiralty parallel provide an additional basis for a broad congressional power pursuant to the foreign relations interest? With respect to the power of Congress to legislate on matters affecting foreign relations in general, see Henkin, supra note 24.

${ }^{40} \mathrm{Cf}$. Bethlehem Steel Co. v. New York State Labor Relations Bd., 330 L.S. 767, 772 (1947); Leisy v. Hardin, 135 U.S. 100, 109 (1890). See also Pennsylvania v. Nelson. 350 U.S. 497 (1956); Hines v. Davidowitz, 312 U.S. 52 (1941).
} 
has not played a dominant role in the domestic development of public or private international law. Whatever the reasons, be they conceptual, political, administrative or simply that the many diverse foreign relations problems which initially arise in the courts are not normally ripe for legislation, Congress has characteristically not solved most of the significant foreign relations questions presented to the courts for decision and has provided even less guidance with respect to the minor, everyday problems affecting foreign relations. Although there are occasional statutes dealing with international law questions likely to arise in the courts, such as diplomatic iminunity, ${ }^{47}$ many of our foreign relations problems, such as the act of state doctrine and recognition of foreign judgments, have remained essentially untouched by Congress. ${ }^{48}$ Thus, the federal legislative power has not proven a completely satisfactory technique for achieving federal control over foreign relations.

In reality, perhaps the most effective means of achieving federal

\$7 See International Organizations Immunities Act $\S 8(\mathrm{a}), 59$ Stat. 672 (1945), 22 U.S.C. § 288e (a) (1958); REv. STAT. $\$ \$ 4065.66$ (1875), 22 U.S.C. $§ 254$ (1958). Although 22 U.S.C. is devoted entirely to foreign relations, most of it is concerned with public law such as that governing the foreign service or United States participation in international organizations.

${ }^{8}$ Shortly after this article was written Congress added a rider to the Foreign Assistance Act of 1964, in effect overturning the Sabbatino rule that the act of state doctrine sometimes prevents inquiry as to the validity of a claim under international law. But by its terms, the rider expires January 1, 1966. "[N]o court in the United States shall decline on the ground of the federal act of state doctrine to make a determination on the merits giving effect to the principles of international law in a case in which a claim of title or other right is asserted by any party including a foreign state ... based upon ... a confiscation or other taking after January 1,1959 , by an act of that state in violation of the principles of international law, including the principles of compensation and the other standards set out in this subsection: Provided, That this subparagraph shall not be applicable ... (2) in any case with respect to which the President determines that application of the act of state doctrine is required in that particular case by the foreign policy interests of the United States and a suggestion to this effect is filed on lis behalf in that case with the court, or (3) in any case in which the proceedings are commenced after January 1, 1966." Foreign Assistance Act of 1964 § 301 (d) (4), 78 Stat. 1013 (1964).

Apparently the rider was passed with no public liearings and little discussion. Lewis, Act of State Doctrine Reaffirmed, N.Y. Times, Nov. 15, 1964, \& 4, p. 5, col. 1. See generally Henkin, Act of State: Sabbatino in the Courts and in Congress-Comments, 3 Colum. J. Trans. L. 99, 107 (1965); Metzger, Act-of-State Doctrine Refined: The Sabbatino Case, 1964 Sup. Cr. REv. 223, 242-47. Needless to say, this act raises weighty questions of the foreign relations power of Congress vis-d-vis the executive and judicial branches which are outside the scope of this paper. For a brief discussion of somewhat similar questions in the context of a state-federal conflict over the possession of submerged gnlf lands, see United States v. Louisiana, 363 U.S. 1, 35 (1960). See also Riesenfeld, The Power of Congress and the President in International Relations: Three Recent Supreme Court Decisions, 25 Calif. L. REv. 643 (1937). 
control over the resolution of foreign relations questions which tend to arise initially in the courts has simply been through use of the State Department suggestion. Questions relating to such areas as sovereign and diplomatic immunity, recognition of foreign judgments and the act of state doctrine, whether arising in state or federal courts, have frequently been resolved by use of the suggestion.99 This has, of course, resulted in some degree of national uniformity with respect to questions of international law and foreign policy.

The use of the executive suggestion as a technique for federal control of foreign relations is not without problems, however, since the suggestion is infrequently utilized outside of a limited class of cases. ${ }^{50}$ For example, once a problem is characterized as one of "conflicts" the suggestion will probably not be employed, even though such characterization almost completely begs the question. Moreover, because of political or other reasons, the executive branch is often hesitant to employ the suggestion, and, in fact, the case may not even come to the attention of the appropriate executive officer. This hesitancy is not always without justification, since the suggestion operates in a twilight zone between executive and judicial power; and, although the suggestion is at least highly persuasive, it may not always be conclusive on a court. ${ }^{51}$ In fact, there are those who argue that in needlessly deferring to the suggestion the courts are abdicating their judicial function, since in the long run the courts may be better suited for the development of questions of international law than is the executive branch. ${ }^{52}$ It would seem that this argument, though, presupposes a federal common law of foreigu relations binding on the states. ${ }^{53}$ Whatever the merits of the executive suggestion, it is clear that it too has failed to afford a technique for complete federal control over foreign relations.

${ }^{\circ}$ See Cardozo, Judicial Deference to State Department Suggestions: Recognition of Prerogative or Abdication to Usurper?, 48 CoRNELr L.Q. 461 (1963); Franck, The Courts, the State Department and National Policy: $A$ Criteria for Judicial Abdication, 44 Minn. L. Rev. 1101 (1960); Jessup, supra note 31; Moore, The Role of the State Department in Judicial Proceedings, 31 FordHAM L. REv. 277 (1962).

${ }_{50}$ The suggestion is primarily utilized in cases dealing with sovereign and diplomatic immunity, recognition of foreign governments, the act of state doctrine, and boundary and territory disputes. See Moore, supra note 49.

52 See authorities cited note 49 supra.

"See Jessup and other authorities cited note 49 supra. See generally FALK, op. cit. supra note 30 .

6s Thus, Professor Jessup argued for a federal common law of foreign relations binding on the states prior to writing his famous article cited in notes 31 and 49 supra. See Jessup, supra note 14. 
The relationship between the legislative, executive and judicial branches with respect to foreign relations has frequently been adverted to, but it has seldom been noticed in this context that the problems inherent in achieving: realistic federal control over individual state action affecting foreign relations call for significant participation by all three branches of the federal government. 'The principal legislative and executive techniques for federal cointrol of foreign relations have achieved substantial dominance over state policies whenever they have been employed. They have not, however, always proven a practical means of controlling the resolution of foreign relations questions arising in the courts. Yet paradoxically, it has been unclear to what extent the federal judiciary, which must necessarily play a significant role in the development of foreign relations, may control state policies in these areas. Although there may be controversy in individual cases as to the competence of the judiciary to handle a particular foreign relations problem, at least some foreign relations questions are going to arise and be finally decided in the courts. Consequently, if the federal government is to control the resolution of foreign relations questions arising in the courts, it would seem to be imperative that there be a federal common law of foreign relations binding on the state courts. And quite aside from any question of executive-judicial conflict with respect to foreign relations, the astonishing fact, in light of our constitutional history, is that the rationale of federal judicial power in foreign relations cases has not been sufficient to dispel all doubt that the federal judiciary is to be dominant over state courts in the area of foreign relations. Nor has there been any realistic appraisal of what should be denominated foreign relations questions. Instead, the question whether state or federal power should be dominant with respect to a particular problem has often been made to depend on conceptual characterizations, such as whether the problem has historically been characterized as one of "conflicts," rather than on an examination of the effect of the problem on foreign relations and the need for a uniform federal policy. It has become evident that if we are to achieve the requisite federal control over foreign relations urgently needed in today's world, a prerequisite is a clear rationale for a broadly conceived federal common law of foreign relations binding on the states. To what extent is there such a rationale today? ${ }^{54}$

si see generally Henkin, The Foreign Affairs Power of the Federal Courts. Sab̄atino, 


\section{III}

\section{The Federal Common Law of Foreign Relations}

As a practical matter, the techniques of federal control over foreign relations previously discussed, combined with the usual willingness of state courts to follow federal policy in matters clearly affecting foreign relations, have resulted in substantial federal dominance over most of the foreign relations problems which arise in state courts. Conceptual difficulties, however, particularly those arising from the dual nature of our court system, have made federal judicial control over the states in this area somewhat uncertain. Perhaps the best example of this uncertainty is afforded by the development and status of the law relating to recognition of foreign judgments. As has been pointed out, the Supreme Court held in 1895 in Hilton $v$. Guyot ${ }^{55}$ that with certain exceptions $s^{56}$ the judgments of a foreign nation will not be given conclusive effect in United States courts unless that nation grants reciprocal effect to United States judgments. ${ }^{57}$ In announcing this rule of reciprocity, the Court acted pursuant to its interpretation of international law, saying that:

It appears, therefore, that there is hardly a civilized nation on. either continent, which, by its general law, allows conclusive effect to an executory foreign judgment for the recovery of money....

[T]he rule of reciprocity has worked itself firmly into the structure of international jurisprudence.

In holding such a judgment, for want of reciprocity, not to be conclusive evidence of the merits of the claim, we do not proceed upon any theory of retaliation upon one person by reason of injustice done to another; but upon the broad ground that international law is founded upon mutuality and reciprocity, and that by the principles of international law recognized in most civilized nations, and by the comity of our own country, which it is our judicial duty to know and to declare, the judgment is not entitled to be considered conclusive. ${ }^{58}$

64 Colum. L. REv. 805 (1964); Comment, Federal Common Law and Article III: $A$ Jurisdictional Approach to Erie, 74 YaLE L.J. 325 (1964).

sb 159 I.S 113 (1895).

${ }^{\circ}$ Id. at 166-71. See Reese, The Status in this Country of Judgments Rendered Abroad, 50 Colum. L. Rev. 783, 791-92 (1950).

s7 159 U.S. at $227-28$.

${ }^{60}$ Ibid. 
This language would seem to indicate that the Court was laying down a rule for both state and federal courts, and another passage in the opinion lends support to this view:

The reasonable, if not the necessary, conclusion appears to us to be that judgments rendered in France, or in any other foreign country, by the laws of which our own judgments are reviewable upon the merits, are not entitled to full credit and conclusive effect when sued upon in this country....58

Thus, the Court in Hilton apparently announced what it considered a rule of public international law binding upon every court in the nation, state or federal. Since under clearly established constitutional principles, the voice of the nation with respect to foreign relations should be a federal one, it would seem logical to expect that the states would follow the Hilton rule as the supreme law of the land. Surprisingly, however, not all of the states have done so. For example, in 1907, California adopted a conclusive effect rule, ${ }^{10}$ apparently assuming that Hilton was not binding on the states. Moreover, in 1926, when the New York Court of Appeals was squarely faced with the question in Johnston $v$. Compagnie Générale Transatlantique, ${ }^{61}$ it explicitly rejected the Hilton rule. Judge Pound, writing for the court, seemed to agree that the states should be bound by Supreme Court determination of foreign relations questions, but he avoided following the Hilton rule by characterizing it as simply a rule of conflicts and evidence. ${ }^{\text {22 }}$ In other words, Judge Pound held that the Hilton decision did not bind the state courts because it involved what he considered questions of private interna-

5o Id. at 227. (Emphasis added.)

${ }^{\circ 0}$ Cal. Crv. Proc. Code $\S 1915$, as amended Cal. Stats. 1907, c. 178, p. 206, $\$ 1$ (1953). For the background on this amendment see Nadelmann, supra note 39 , at 252 . 53.

61242 N.Y. 381,152 N.E. 121 (1926).

"To "That extent is this court bound by Hilton $v$. Guyot? It is argued with some force that questions of international relations and the comity of nations are to be determined by the Supreme Court of the United States; that there is no such thing as comity of nations between the State of New York and the Republic of France; and that the decision in Hilton $v$. Guyot is controlling as a statement of the law. But the question is one of private rather than public international law, of private right rather than pubhic relations, and our courts will recognize private rights acquired under foreign laws and the sufficiency of the evidence establishing such rights. A right acquired under a foreign judgment may be established in this State without reference to the rules of evidence laid down by the courts of the United States. Comity is not a rule of law, but it is a rule of "practice, convenience and expediency. . ." Id. at $386-87,152$ N.E. at 128. 
tional law and evidence, questions which were within the competence of the state courts. It should be emphasized that Judge Pound was not asserting that there was no federal common law of foreign relations binding on the states; instead he was simply taking advantage of a somewhat ambiguous Supreme Court opinion in order to avoid following a decision with which he did not agree. In so doing, it would seem that he took an unjustifiably narrow view of what is embraced by the term foreign relations. It seems doubtful that the international law to which the Supreme Court adverted was intended to be private rather than public. In any event, the facile classification of a problem under the ubiquitous heading of conflicts or private international law largely begs the question. The real question is whether the problem has a sufficiently substantial effect on foreign relations to require a national policy making responsibility or a uniform national rule for effectuation of foreign policy. New York has, however, continued to evade the Hilton rule by characterizing the problem as one of "private rights." 63 In addition, other state courts have followed the New York and California rules, at least in dicta, although few have been faced with the problem as squarely as was the New York court. ${ }^{64}$ Finally, to add insult to injury the Restatement of The Conflict of Laws adopted the New York rule. ${ }^{65}$ On the other hand, a number of states have followed the Hilton rule, regarding it as a Supreme Court determination on a foreign relations question. ${ }^{66}$ The unhappy result, of course, is a divergence of views within the United States regarding the recoguition of foreign judgments.

As if these uncertainties were not enough, the problem was further complicated by the decisions in Erie R.R. v. Tompkins ${ }^{67}$ in 1938, and Klaxon Co. v. Stentor Elec. Mfg. Co. ${ }^{68}$ in 1941. Erie, it

"s Cowans v. Ticonderoga Pulp \& Paper Co., 219 App. Div. 120, 219 N.Y.S. 284 (1927).

o< See Bonfils v. Gillespie, 25 Colo. App. 496, 139 Pac. 1054 (1914) (dictum); Coulborn v. Joseph, 195 Ga. 723, 25 S.E.2d 576 (1943). See generally Smith, supra note 33, at $7 \cdot 16$.

os "A foreign money judgment will be enforced although the judgments of the forum are not enforced in the foreign state." RESTATEMENT, CONFLICr of LAwS $\$ 434$, comment $b$ (1934).

${ }^{\circ 0}$ See Traders Trust Co. v. Davidson, 146 Minn. 224, 178 N.W. 735 (1920); Banco Minero v. Ross, 106 Tex. 522, 172 S.W. 711 (1915). See generally Smith, supra note 33, at 7-16.

02304 U.S. 64 (1938).

88313 U.S. 487 (1941). 
will be recalled, held broadly that the federal courts were generally bound to follow state substantive law on non-federal matters. In fact, the Court's somewhat over-enthusiastic opinion declared: "There is no federal general common law." held that substantive law includes conflict of laws rules. These decisions not only left unanswered the question whether state courts should follow the Hilton rule but, since New York and other jurisdictions had classified this problem as one of conflicts, they created uncertainty as to whether the federal courts had to follow state rules on the enforcement of foreign judgments when they differed from the Hilton rule. If recognition of foreign judgments was a local problem which could best be handled by the states individually it would not be illogical to require the federal courts to follow state rules, since presumably the strong Erie policy of uniformity of result in state and federal courts would take precedence over the Hilton decision. Since recognition of foreign judgments is not a local problem, however, application of the Erie rationale in this area would produce a completely anomalous result.

The question whether the federal courts must follow state rules on recognition of foreign judgments appears never to have been squarely decided. In Compania Mexicana Rediodifusora Franteriza v. Spann ${ }^{70}$ decided in 1941, the federal district court for the northern district of Texas was faced with deciding what effect a Mexican money judgment should be given. Since it was assumed that Mexico gave reciprocal effect to United States judgments, however, no conflict between the state and federal rules was discussed. Furthermore, although not mentioned in the opinion, an earlier state court decision seemed to indicate that Texas followed the Hilton rule. ${ }^{71}$ In - Gull $v$. Constam, ${ }^{72}$ decided in 1952, a federal district court in Colorado impliedly adverted to the Erie-Hilton problem but avoided deciding it by ruling that no allegation of reciprocity was necessary in order for the complaint to be valid under either the state or Hilton rule. Moreover, the authority contra to Hilton in Colorado consisted only of dictum in a 1914 interstate judgments case indicating

00 U.S. at 78.

${ }^{70} 41$ F. Supp. 907 (N.D. Tex. 1941), aff'd, 131 F.2d 609 (5th Cir. 1942), 30 Geo. L.J. 478 (1942).

7 See Banco Minero v Ross, 106 Tex. 522, 172 S.W 711 (1915).

72105 F Supp. 107 (D. Colo. 1952), 38 Cornell L.Q. 423 (1953). 
that the modern trend in the country was toward giving conclusive effect to foreign judgments. ${ }^{73}$

Although these cases are indicative of the confusion created by the Erie-Hilton problem, ${ }^{74}$ it is perhaps significant that the district courts involved refrained from expressly finding that they were not bound by the Hilton rule, since generally speaking, the rule has not met with great favor ${ }^{75}$ and the logic of Erie would have been a convenient way out. What has been overlooked by those who disagree with the rule is that recognition of foreign judgments is a federal problem requiring a federal solution, the merits of Hilton notwithstanding. ${ }^{76}$ Perhaps if that factor had been appreciated from the outset, the problem of recognition of foreign judgments would not remain hopelessly confused some seventy years after the decision in Hilton, and in fact the Hilton rule itself might have long since been scrapped. If Hilton was erroneously decided, then the solution is to change the federal rule, not to encourage a hodgepodge of independent state rules. In any event, the independent state positions regarding the problem, although perhaps more enlightened on the merits, have failed to achieve the foreign relations goal sought, namely the recognition of United States judgments abroad by reciprocity nations. Thus, the lesson of Hilton reaffirms that the voice of foreign relations must be a federal voice.

Traditionally, public international law is applicable only between nations. Since it is based in large measure on the practice of nations and international custom, however, such law can be influenced significantly by decisions of national courts. ${ }^{77}$ Cases involving such matters as sovereign and diplomatic immunity and recognition of foreign judgments are frequently entertained by national courts, and the decisions of such courts go far toward shaping international practice. In this regard, the courts of the United States are no exception, and in recent years they have played an increasingly important

\footnotetext{
${ }^{73}$ Bonfils v. Gillespie, 25 Colo. App. 496, 139 Pac. 1054 (1914).

"For discussion of the Erie-Filton problem, see Nadelmann, supra note 33, at 241; Reese, supra note 56, at 786-88; Smith, supra note 33, at 14-16.

${ }^{73}$ See 2 Beale, The Conflict of LAws $\$ 434.3$ (1935); GoOdRich, Conflict of LAws 606-07 (3d ed. 1949); Nadelmann, supra note 35. But for a more neutral position suggesting that Hilton might provide the State Department with a useful hargaining weapon, see Reese, supra note 56 , at 793.

70 At least one other commentator has suggested that the problem is one of foreign relations requiring a federal solution. See Reese, supra note 56 , at 788 .

77 See Bishor, International Law 37 (2d ed. 1962); Dickinson, supra note 30.
} 
role in the development of international law. Since cases involving international law problems usually involve diversity of citizenship, they are largely decided in this country in the federal courts. The state courts, however, have concurrent jurisdiction to hear most such cases, and this jurisdiction is exercised fairly frequently. ${ }^{78}$ This overlap of jurisdiction once again raises the spectre of Erie. Prior to the Erie decision there would have been little disagreement with the proposition that the Supreme Court should be the final judicial source for declaring the United States' position on questions of public international law. Any suggestion that the state courts should be free to take individual positions on public international law questions would, in all probability, have met with ridicule. As long ago as 1816, the Louisiana Supreme Court declared that:

Of the extent or authority, which judgments of the supreme tribunal of the country, declaring the law of nations, ought to have, there can be hardly any doubt. Whatever be the jurisprudence of other governments, the United States, as a nation, can have but one rule of conduct towards the others. In that code of national rights, called the law of nations, each nation is considered as an individual: the United States are one, the particular states are nothing. ${ }^{79}$

The strong language of Erie, however, even managed to obscure this obvious proposition, for in the wake of Erie at least one court of appeals intimated that the federal courts were bound to follow state court determinations on international law questions.

In Bergman v. De Sieyes, ${ }^{80}$ decided in 1948, a French minister was served in New York with civil process in an action for deceit while en route to his post in La Paz, Bolivia. The case was removed from the state court to a federal district court on grounds of diversity of citizenship. New York state courts had taken the position that a diplomat in transitu was entitled to the same immunity as a diplomat in situ. In adopting the New York position on this essentially international law question, Judge Learned Hand, writing for the Court of Appeals of the Second Circuit, said: "[A]lthough the courts of [New York] ... look to international law as a source of New York law, their interpretation of international law is controlling upon us,

${ }^{28}$ See cases cited note 9 supra.

70 Blanque v. Peytavin, 2 Mart. (4 Mart.) 458. 461 (La. 1816).

so 170 F.2d 360 (2d Cir. 1948), 33 MrNN. L Rev. 540 (1949). 
and we are to follow them so far as they have declared themselves." 81 Judge Hand carefully qualified this statement, however, saying: "Whether an avowed refusal to accept a well-established doctrine of international law, or a plain misapprehension of it, would present a federal question we need not consider, for neither is present here."82 Judge Hand thus recognized the obvious dangers inherent in allowing state interpretations to completely control the United States' position on questions of international law. It is anomalous, however, to assert that the federal courts are bound by state court determinations on questions of international law to any extent. Such an interpretation of Erie would create the possibility of the United States having fifty different positions on a question of international law. Certainly Erie was not meant to apply in this area. Indeed the uniformity of result in state and federal courts sought to be achieved by Erie can be achieved equally well and with a great deal more constitutional justification in foreign relations cases by requiring the states to follow the federal position. It would certainly be absurd for New York to grant diplomatic immunity to a minister in transitu in a situation in which California refused to do so, or for California to allow a foreign sovereign to sue in its courts when New York would not.

In 1939, shortly after the decision in Erie, Professor Philip G. Jessup warned of the dangers of applying Erie to questions of international law, stating that: "The several states of the Union are entities unknown to international law. It would be as unsound as it would be unwise to make our state courts our ultimate authority for pronouncing the rules of international law."83 The warning was prophetic, but it was not unitil 1964 that the Supreme Court, in considering the act of state doctrine, finally put to rest the spectre of Erie with regard to a federal common law of foreign relations. In so doing, the Court reaffirmed that uniformity in this area can best be achieved by the states following the federal lead.

The act of state doctrine is another area in which the broad ErieKlaxon rationale has led to conceptualistic confusion. The act of state doctrine was set out by the Supreme Court in the 1897 case of

${ }^{81}$ Id. at 361 .

${ }^{82}$ Ibid.

${ }^{88}$ Jessup, The Doctrine of Erie Railroad v. Tompkins Applied to International Law, 33 AM. J. INT'L L. 740, 743 (1989). 
Underhill v. Hernandez. ${ }^{84}$ As subsequently developed, it constitutes a judicially created rule of foreign relations to the effect that normally the judicial branch will not examine the validity of foreign acts of state executed within the foreign state's own territory. Historically, the rule seems to be based on an inextricable mixture of public international law, foreign policy and notions concerning the proper relationship between the executive and the judiciary on questions of foreign relations. ${ }^{85}$ In the pre-Erie case of Oetjen $v$. Central Leather $\mathrm{Co}_{0}{ }^{86}$ the Supreme Court strongly implied that the rule was binding on all American courts, state or federal:

It is not necessary to consider, as the New Jersey court did, the validity of the levy of the contribution made by the Mexican commanding general, under rules of international law applicable to the situation, since the subject is not open to reëxamination by this or any other American court. ${ }^{87}$

This language, appearing in the context of the review of a state court decision, strongly suggests that the Court was referring to both state and federal courts. That there subsequently could have been any doubt that this matter might be left to individual state determination is mute testimony to the confusion powers of Erie and Klaxon, and doubt there has been since the decision in Erie. Since Erie asserted that there was no general federal common law, and since it was easy to characterize act of state as a conflicts problem under the rationale of Klaxon, it seemed to follow that state court determinations on act of state were binding on the federal courts. Such reasoning, of course, ignored the fact that the act of state doctrine is at least partly a rule of foreign relations which certainly was not meant, either by the Constitution or by Erie, to be subject to individual state determination. ${ }^{88}$

The Second Circuit, in the recent case of Banco Nacional de

86 168 U.S. 250 (1897).

${ }^{85}$ To the effect that it is not a rule required by public international law, see, e.g., Banco Nacional de Cuba v. Sabbatino, 376 U.S. 398, 428 (1964); CARLston, LAW AND Organization in World SOCIETY 269 (1962). But see authorities cited in Henlin, supra note 54 , at 819 n.48.

${ }^{88} 246$ U.S. 297 (1918).

${ }^{87}$ Id. at 304 . (Emphasis added.)

${ }^{88}$ Professor Baade has adverted to this problem and suggests that the act of state doctrine is at least partly a rule of judicial abstention and as such should be binding on the entire federal judiciary. Baade, The Legal Effect of Cuban Expropriations In the United States, 1963 DURE L.J. 290, 801. 
Cuba v. Sabbatino, ${ }^{89}$ adverted to this Jogical paradox with respect to Erie and the act of state doctrine but avoided the problem by finding that the New York and federal positions on act of state were identical:

We mention one further problem related to this case which we find unnecessary to settle but which may arise to torment some future court with a case similar to the present one. That problem is whether the law governing this case involves elements of federal law or whether the case is governed solely by New York law.... It has been said that the act of state doctrine is part of the law of conflict of laws. If that is so, it would seem that under the rule in Klaxon Co. v. Stentor Elec. Mfg. Co.... it is New York law which we are applying. On the other hand, certain cases have indicated that international law is part of the body of federal law.... Perhaps Erie R.R. v. Tompkins has changed the rule in these latterly mentioned cases.... For our purposes here we do not have to resolve these questions because it appears to us that a New York court would reach the same result we reach. ${ }^{80}$

Although the doubt expressed in the opinion that such questions are controlled by federal law is itself shocking, even after the broad Erie decision, perhaps one can take comfort in the fact that the question was merely adverted to. Apparently no court has actually held in the context of a clear state-federal conflict that such questions are included in the Erie rationale. In any event, when the case reached the Supreme Court in 1964, any ideas that international law or legal problems affecting international relations come under the rationale of Erie-Klaxon, or that the states are free to formulate their own rules on such questions, were finally put to rest. Mr. Justice Harlan, writing for eight members of the Court, said:

Whatever considerations are thought to predominate, it is plain that the problems involved are uniquely federal in nature. If

${ }^{80} 307$ F.2d 845 (2d Cir. 1962), rev'd, 376 U.S. 398 (1964). See generally Collinson, Sabbatino: The Treatment of International Law in United States Courts, 3 CouUM. J. Trans. L. 27 (1964); Falk, The Complexity of Sabbatino, 58 AM. J. INT'亡 I. 935 (1964); Falk, The Case of Banco Nacional de Cuba v. Sabbatino Before the Supreme Court of the United States, 9 How. L.J. 116 (1963); Falk, Toward A Theory of the Participation of Domestic Courts in the International Legal Order: $A$ Critique of Banco Nacional de Cuba v. Sabbatino, 16 Rutcers L. Rev. I (1961); Henkin, supra note 54; Reeves, The Sabbatino Case: The Supreme Court of the United States Rejects a Proposed New Theory of Sovereign Relations and Restores the Act of State Doctrine, 32 FORDHAM I. Rev. 631 (1964); Stevenson, The State Department and Sabbatino-"Ev'n Victors Are By Victories Undone," 58 AM. J. INT'L L. 707 (1964). See also discussion and authorities cited in note 48 supra.

90307 F.2d at 869 n.16. 
federal authority, in this instance this Court, orders the field of judicial competence in this area for the federal courts, and the state courts are left free to formulate their own rules, the purposes behind the doctrine could be as effectively undermined as if there had been no federal pronouncement on the subject.

[W] are constrained to make it clear that an issue concerned with a basic choice regarding the competence and function of the Judiciary and the National Executive in ordering our relationships with other members of the international community must be treated exclusively as an aspect of federal law. It seems fair to assume that the Court did not have rules like the act of state doctrine in mind when it decided Erie R. Co. v. Tompkins. Soon thereafter, Professor Philip C. Jessup, now a judge of the International Court of Justice, recognized the potential dangers were Erie extended to legal problems affecting international relations. He cautioned that rules of international law should not be left to divergent and perhaps parochial state interpretations. His basic rationale is equally applicable to the act of state doctrine. ${ }^{01}$

Mr. Justice White's dissenting opinion did not indicate disagreement on these points. ${ }^{92}$

The Court was obviously correct in concluding that questions of foreign relations were not meant to come within the Erie rule, for Erie simply asserted that on questions of non-federal significance the federal courts must follow state substantive law. Whether constitutionally compelled or not, ${ }^{93}$ Erie simply sought to achieve state control over matters of local substantive law and at the same time to achieve uniformity of result between state and federal courts. But if Erie is read as applicable to foreign relations questions, then it loses all constitutional and policy justification. The Constitution unmistakably contemplates exclusive federal control over foreign relations. ${ }^{94}$ Moreover, since foreign relations questions are not matters of local concern, Erie should not require federal deference to state court determination of such questions. Indeed, the policy of Erie to promote uniformity of result requires the state courts to follow the federal lead on questions of federal significance. That, quite simply, should be the constitutional and policy lesson of Erie with respect to foreign relations questions.

\footnotetext{
91376 U.S. at 424, 425. See generally Henkin, supra note 54.

02376 U.S. at 439.

${ }^{2}$ See Friendly. In Praise of Erie-And of the New Federal Common Law, 39 NंY Li.L REv. 383, 385-86 (1964).

* See constitutional provisions cited note 3 supra.
} 
The Erie opinion also indicated that there are few common law questions of federal significance. Yet it can hardly be read as asserting that questions of foreign relations are not of federal significance. Arguably, such an interpretation would itself be unconstitutional, and certainly nothing in the Rules of Decision Act ${ }^{95}$ requires such a reading. It would seem, instead, that the Court simply did not advert to the foreign relations problem at all, but felt it necessary to write a strong opinion in order to overturn an established practice. As the Court pointed out in Sabbatino, the fact that Erie did not mean strictly what it said is borne out by the decision in Hinderlider v. La Plata River \& Cherry Creek Ditch Co.,96 decided the same day as Erie and written by the same author, which held that apportionment of the water from an interstate stream is a question of federal common law. ${ }^{97}$ This and other cases point out the wellaccepted fact that despite Erie there are areas of federal common law that bind the states.98

An apt parallel to the effect of Erie on the federal foreign relations power can be found in the admiralty cases. Since the pre-Erie decision in Southern Pac. Co. v. Jensen, ${ }^{99}$ it has been generally accepted that federal law, whether statutory or judicially created, largely governs admiralty and maritime matters, even when cases involving such matters are brought in state courts under the saving clause. ${ }^{100}$ Although immediately after the Erie decision there was some speculation that it applied to admiralty questions, ${ }^{101}$ it is now clear that it does not, at least with respect to such questions which require uniform resolution. ${ }^{102}$ On such questions, the states are bound by federal common law. The rationale for the federal

\footnotetext{
${ }^{05}$ Judiciary Act of 1789 § 34, Rev. STAT. § 721 (1875) (now 28 U.S.C. § 1652 (1958)).

${ }^{\circ 0} 304$ U.S. 92 (1938). See the discussion of the Hinderlider case in Friendly, supra note 93 , at 408 n.119.

o7 376 U.S. at 425 .

${ }^{88}$ See Friendly, supra note 93, at 408-22.

244 U.S. 205 (1917).

100 Behind this oversimplification lies the essence of an admiralty course. For an introduction see GILMORE \& BLACK, THE LAW OF ADMIRALTy 43-46 (1957); D. Currie, Federalism and the Admiralty: "The Devil's Own Mess," 1960 Sup. Cr. REv. 158. "Thus, if one thing is clear it is that the source of law in saving-clause actions cannot be described in absolute terms. Maritime law is not a monistic system." Romero v. International Terminal Operating Co., 358 U.S. 354, 374 (1959).

${ }^{202}$ See Stevens, Erie R.R. v. Tompkins and the Uniform General Maritime Law, 64 HARV L. REv. 246 (1950).

${ }^{102}$ Pope \& Talbot, Inc. v. Hawn, 346 U.S. 406, 409-11 (1953). See Friendly, supra note 93 , at $404-05$.
} 
admiralty power is that since by its very nature admiralty primarily involves interstate and international intercourse, it requires a uniform federal law which is effective and nationally responsive. A fortiori, this reasoning is applicable to foreign relations questions.

Perhaps one of the reasons that there has been so much conceptual difficulty with respect to the effect of Erie on the foreign relations power is that there are no explicit article three provisions extending the federal judicial power to foreign relations questions as such, as there are with respect to interstate disputes and admiralty matters. This raises the question whether there is a constitutional basis for a federal common law of foreign relations. ${ }^{103}$ of course, it could be argued that even if there is no such basis, Erie is still inapplicable in this area in view of the fact that the Constitution, taken as a whole, rather clearly denies the foreign relations power to the states and vests it exclusively in the federal government. Thus, at the very least, the Court could prevent the states from making determinations on foreign relations questions. Yet this argument proves too much, since these questions frequently arise in state courts; and in the absence of federal legislative or executive guidance it is impossible to prevent state determinations on foreign relations questions in these cases except by a judicially created federal rule, since some decision usually must be reached. In short, if there is no constitutional basis for a federal common law of foreign relations, then there is no basis for adequate federal control over state foreign relations decisions.

With respect to interpretations of public international law, there is little constitutional difficulty in finding that the Supreme Court is the final authority in this country. The usual rationale for such authority is that in announcing a rule of international law the Court is not acting pursuant to federal common law but is merely interpreting existing international rules. ${ }^{104}$ This avoids the necessity of finding a constitutional basis for a federal common law of foreign relations, even though actually the Court may be making federal common law in a very real sense in view of the fact that

\footnotetext{
${ }^{108}$ The leading article here is Henkin, The Foreign Affairs Power of the Federal Courts: Sabbatino, 64 Colum. L. REv. 805 (1964). As this paper demonstrates, while profiting from his ideas, I cannot agree with Professor Henkin's skepticism as to the constitutional justification or necessity for a federal common law of foreign relations binding on the states. See Comment, Federal Common Law and Article III: a Jurisdictional Approach to Erie, 74 YALE I.J. 325 (1964).

so4 See. e.g., The Paquete Habana. 175 U.S. 677 (1900)
} 
our law may shape international law which in turn is a part of our own law. Since this constitutional justification merely requires characterization of a particular problem as one involving public international law, there should be little conceptual difficulty in achieving substantial federal control over foreign relations questions, most of which can easily be so characterized. ${ }^{105}$ However, this rather fictional analysis is defective in that it does not provide a rationale for federal judicial determination of those foreign relations questions which may be devoid of international law significance. In any event this approach should be unnecessary.

In the Sabbatino case the Supreme Court carefully considered and rejected the notion that adherence to the act of state doctrine is required by public international law. ${ }^{106}$ Although the Court based its decision to follow the act of state doctrine on requirements of the proper relationship between the executive and judicial branches of our government, ${ }^{107}$ it arguably relied at least in part on a federal common law of foreign affairs.108 To this extent, then, the Court was asserting constitutional authority for a broad federal common law of foreign relations. In so doing, it emphasized that act of state problems are federal problems which must be resolved by federal law:

We conclude that the scope of the act of state doctrine must be determined according to federal law. ${ }^{109}$

Various constitutional and statutory provisions indirectly support this determination ... by reflecting a concern for uniformity in this country's dealings with foreign nations and indicating a desire to give matters of international significance to the jurisdiction of federal institutions. ${ }^{110}$

This determination that act of state problems must be governed by federal law and the Court's indication that there is a constitutional basis for a federal common law of foreign relations seem entirely justified, for although it is true that article three has no provision explicitly extending the federal judicial power to foreign relations questions as such, many of its provisions are obviously calculated to make the federal judiciary supreme on questions which

\footnotetext{
${ }^{108}$ This suggestion is made by Henkin, supra note 103, at 819-20.

106376 U.S. at 421 .

${ }^{107} I d$. at 427-28.

${ }^{208}$ Sce Henkin, supra note 103 , at 813 .

200376 U.S. at 427.

${ }^{130}$ Id. at 427 n.25.
} 
might involve the international relations of the nation. For example, article three extends the federal judicial power to cases arising under treaties made under the authority of the United States, to all cases affecting ambassadors and consuls, to all cases of admiralty jurisdiction, and to controversies between a state or its citizens and foreign states or citizens. As Hamilton pointed out in The Federalist Papers, these powers were given to the federal judiciary largely to insure national control of questions affecting the foreign relations of the nation:

It seems scarcely to admit of controversy, that the judiciary authority of the Union ought to extend to these several descriptions of cases: ...4 4th, to all those which involve the PEACE of the CONFEDERACY, whether they relate to the intercourse between the United States and foreign nations, or to that between the States themselves; 5 th, to all those which originate on the high seas, and are of admiralty or maritime jurisdiction....

The fourth point rests on this plain proposition, that the peace of the WHOLE ought not to be left at the disposal of a PART. The Union will undoubtedly be answerable to foreign powers for the conduct of its members. And the responsibility for an injury ought ever to be accompanied with the faculty of preventing it....

The fifth point will demand little animadversion. The most bigoted idolizers of State authority have not thus far shown a disposition to deny the national judiciary the cognizance of maritime causes. These so generally depend on the laws of nations, and so commonly affect the rights of foreigners, that they fall within the considerations which are relative to the public peace....

[T]he judicial authority of the Union ... is ... to extend: ...

Second. To treaties made, or which shall be made, under the authority of the United States, and to all cases affecting ambassa. dors, other public ministers, and consuls. These belong to the fourth class of the enumerated cases, as they have an evident connection with the preservation of the national peace.

Third. To cases of admiralty and maritime jurisdiction. These form, altogether, the fifth of the enumerated classes of causes proper for the cognizance of the national courts....

Seventh. To cases between a State and the citizens thereof, and foreign States, citizens, or subjects. These have been already explained to belong to the fourth of the enumerated classes and have been shown to be, in a peculiar manner, the proper subjects of the national judicature. ${ }^{111}$

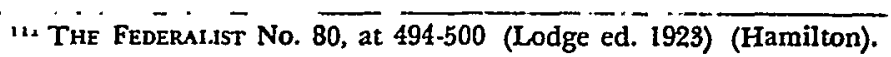


Apparently the framers of the Constitution were careful to give power to the federal judiciary in practically every type of case commonly involving foreign relations. In the face of this rather pronounced plan and its background at the constitutional convention, ${ }^{112}$ it seems logical to conclude that article three authorizes broad federal jurisdiction over foreign relations questions. Nor should it be fatal to this plan that the framers did not advert to every possible case in which foreign relations questions might be presented to the courts in the future. It would seem, then, that there is at least as strong a case for a federal common law of foreign relations in general as there is for a federal common law of admiralty or interstate disputes.

Admittedly, a federal common law of foreign relations would be subject to abuse should the courts not exercise it with restraint, recognizing that the other branches of government may have superior competency to deal with many international problems. If anything, however, the courts have shown every indication of deference to the other branches of government on foreign relations questions, particularly to the executive branch, ${ }^{113}$ and Sabbatino is no exception. To admit that there is a constitutional basis for a federal common law of foreign relations is not to assert that the judiciary will reign supreme in this area vis-à-vis the other branches of government. It simply recognizes the fact that such questions do arise in the courts and must be decided by them, frequently without clear guidance from the other branches of government. If we are to have effective federal control of foreign relations and a uniform United States position on foreign relations questions, we must have a federal common law of foreign relations. Sabbatino stands for this proposition.

It is not sufficient, however, simply to have a federal common law of foreign relations; such law must be binding on the states if national uniformity and federal responsibility for foreign relations is to be achieved. That a prime objective of the Constitution was to

112 That the Court was to have power over foreign relations questions seems implicit in most of the plans proposed at the constitutional convention. See WArren, The Makinc of THE Constitution 329-31, 534-47 (1928). Particularly is this so with respect to the broad outline adopted by the convention on July 18, 1787, which read: "That the jurisdiction of the National Judiciary shall extend to cases under laws passed by the General Legislature; and to such other questions as involve the National peace and harmony." Id. at 331.

${ }^{11}$ See authorities cited note 49 supra. 
centralize the foreign relations power is evident from a variety of constitutional provisions. ${ }^{114}$ These provisions, coupled with relevant historical interpretations ${ }^{115}$ and subsequent foreign relations decisions of the Supreme Court, ${ }^{118}$ demonstrate beyond doubt that the federal foreign relations power is supreme and exclusive. Thus, it should be clear that a federal common law of foreign relations would be binding on state courts. The fact that there is no specific constitutional provision requiring the state courts to follow a federal common law of foreign relations should be given little weight, for the overall constitutional plan is patent. In fact, Mr. Chief Justice Taney's opinion in Holmes $v$. Jennison ${ }^{117}$ shows unmistakably that the federal foreign relations power flows from the Constitution as a whole and that the absence of specific prohibitions on state power in this area does not prevent this federal power from being exclusive. ${ }^{118}$

On a more legalistic level, there are several constitutional provisions which can reasonably be interpreted as supporting this conclusion. Most obviously, the supremacy clause ${ }^{110}$ itself would seem to assure the dominance of a federal common law of foreign relations. Since the supremacy clause was designed to render state judiciaries subservient to federal law in general, it was certainly intended to insure federal dominance on questions left exclusively to the United States under the Constitution. Of course it has been questioned whether the phrase "the laws of the United States" in the supremacy clause includes federal common law, ${ }^{120}$ but the cases decided by the Supreme Court in the interstate disputes ${ }^{121}$ and admiralty ${ }^{122}$ areas

\footnotetext{
${ }^{226}$ See constitutional provisions cited note 3 supra.

118 See The Federalist Nos. 3, 4, 5, 22, 42, 80. See generally WARREN, op. cit. supra note 112 .

${ }^{120}$ See, e.g., United States v. Pink, 315 U.S. 203 (1942); United States v. Belmont, 301 U.S. 324 (1937); United States v. Curtis-Wright Export Corp., 299 U.S. 304 (1936); Holmes v. Jennison, 39 U.S. (14 Pet.) 540 (1840).

${ }^{217}$ Ibid.

11839 U.S. (14 Pet.) at 561 . But see the opinions of Justices Tompson, Barbour, Catron and Baldwin which seem to take a narrower view of the federal foreign relations power. Id. at 579, 586, 594, 614 .

228 U.S. CoNST. art. VI, § 2.

${ }^{120}$ See Henkin, supra note 103, at 816.

121 "Under the Compact Clause, however, the federal questions are the execution, validity and meaning of federally approved state compacts. The interpretation of the meaning of the compact controls over a state's application of its own law through the Supremacy Clause and not by any implied federal power to construe state law." Dyer v. Sims, 341 U.S. 22, 33 (1951) (Mr. Justice Reed concurring). See Delaware River Comm'n v. Colburn, 310 U.S. 419 (1940); Hinderlider v. La Plata River \& Cherry Creek Ditch Co., 304 U.S. 92 (1938).

${ }^{122}$ See Pope \& Talbot, Inc. v. Hawn, 346 U.S. 406 (1953); GiLMORE \& BLACK, op. cit. supra note 100 , at $43-46$.
} 
cast serious doubt on this limitation as a general proposition. Certainly it seems unduly technical to assert that this phrase would not include a federal common law dealing with foreign relations questions, since there is little doubt as to the overall purpose of the Constitution or the supremacy clause with respect to such questions.

Even aside from arguments based on the supremacy clause or the Constitution as a whole, it can be argned that federal common law, constitutionally authorized by implication under article three, carries its own implied supremacy. ${ }^{\mathbf{1 2 3}}$ Since the constitutionally sanctioned objective of federal common law is to assure federal dominance in a given area, it follows that state courts must be bound by such law. Federal common law relating to interstate disputes and admiralty, for example, has been held binding on the states. ${ }^{124} \mathrm{~A}$ federal common law of foreign relations should be no exception.

In most cases, state courts have been careful to follow the federal lead on questions involving foreign relations. When they do not, however, as is the case with regard to recognition of foreign judgments, adequate federal review power is necessary in order to insure the effectiveness of a federal common law of foreign relations. Of course, even in the absence of such review power it may be argued that federal law is binding on the state courts in this area, but as the present status of the recognition of foreign judgments problem indicates, this alternative is unsatisfactory. To the extent that such review power is lacking, then, there is a serious deficiency in federal control over foreign relations.

In this respect, there is some question whether the existing scheme provides sufficient federal review power over state court decisions. ${ }^{125}$ The problem arises from the narrow language of 28 U.S.C. section 1257 , the general provision relating to federal review of state court decisions. Section 1257 provides:

Final judgments or decrees rendered by the highest court of a State in which a decision could be had, may be reviewed by the Supreme Court as follows:

(1) By appeal, where is drawn in question the validity of a treaty or statute of the United States and the decision is against its validity.

(2) By appeal, where is drawn in question the validity of a statute of any state on the ground of its being repugnant to the

123 See Henkin, supra note 103 , at 816 n.34.

124 See cases and authorities cited notes 121, 122 supra.

${ }^{125}$ See authorities cited note 11 supra. 
Constitution, treaties or laws of the United States, and the decision is in favor of its validity.

(3) By writ of certiorari, where the validity of a treaty or statute of the United States is drawn in question or where the validity of a State statute is drawn in question on the ground of its being repugnant to the Constitution, treaties or laws of the United States, or where any title, right, privilege or immunity is specially set up or claimed under the Constitution, treaties or statutes of, or commission held or authority exercised under, the United States.120

This provision undeniably grants the Supreme Court ample review power over state court decisions controlled by a treaty or federal statute or where a state statute is involved, but the word "statutes" in the last paragraph arguably indicates that such decisions involving rights claimed under federal common law are not reviewable. Such an interpretation would create a defect in the Court's review power which almost certainly was not adverted to by Congress at the time of the enactment of the Judiciary Act. Moreover, it is doubtful that Congress would have intended this result if the problem had been considered, for such a defect in the review power of the Court would mean that constitutionally authorized federal common law could not be enforced in the state courts.

Despite this perhaps inadvertent congressional use of the word "statutes," section 1257 nevertheless arguably grants adequate federal review power over state court decisions involving rights claimed under constitutionally authorized federal common law, since that section specifically authorizes Supreme Court review of state determinations regarding rights claimed "under the Constitution." The difficulty here, of course, is to find that constitutionally authorized federal common law presents rights claimed under the Constitution for purposes of section 1257. There is some support for this proposition in the interstate disputes cases. In Hinderlider v. La Plata River \& Cherry Creek Ditch Co., ${ }^{127}$ for example, the Supreme Court reviewed a decision of the Supreme Court of Colorado on certiorari despite the fact that neither a treaty nor a statute was involved in the lower court's decision. The case takes on added significance in view of the fact that the question of the Supreme Court's power to review such a decision was carefully argued. ${ }^{128}$ The Court specifically found

\footnotetext{
12028 U.S.C. $\S 1257$ (1958). (Emphasis added.)

237904 U.S. 92 (1938).

${ }^{228}$ Id. at $94-95$, 101 .
} 
without dissent that although a congressionally approved interstate compact would not constitute a statute so as to permit an appeal from a state court decision adverse to its validity, controversies concerning interstate disputes which are governed by federal common law involve claims "under the Constitution" which may be reviewed by certiorari.129 Apparently the only constitutional question presented in the case was simply the supremacy of the federal common law of interstate disputes, and no constitutional question was adverted to in the usual sense of a decision depending upon varying interpretations of a particular provision of the Constitution. SimiJarly, in Delaware River Comm'n v. Colburn ${ }^{130}$ the Supreme Court unanimously held that construction of an interstate compact authorized by the Constitution "involves a federal 'title, right, privilege or immunity' which when 'specially set up and claimed' in a state court may be reviewed here on certiorari under [section 1257] ...."131 Here again it was argued that the Court lacked jurisdiction to review such a decision in the absence of a treaty or federal statute. ${ }^{132}$ Again the Court specifically rejected the contention, this time overruling an earlier Supreme Court decision which had held that there was no jurisdiction to review such an interstate compact case. ${ }^{133}$ These and similar decisions ${ }^{134}$ clearly indicate that in at least some areas governed by a constitutionally authorized federal common law the Supreme Court has taken a broad view of section 1257 commensurate with the need for a national review power on such questions. It would seem that the case for such an interpretation of that section is at least as strong in the foreign relations area.

These arguments are only slightly tarnished by the 1959 Supreme Court decision in Romero $v$. International Terminal Operating Co. ${ }^{135}$ In Romero, Mr. Justice Frankfurter, writing for five members of the Court, expressly rejected the contention that cases involving the federal common law of admiralty arise under the Consti-

\footnotetext{
${ }_{120}$ Id. at $109-10$.

280910 U.S. 419 (1940).

131 Id. at 427 .

$282 \mathrm{Id}$. at 423 .

18s Id. at 427 .

286 See Dyer v. Sims, 341 U.S. 22, 26, 30 (1951); cases cited in Hinderlider v. La Plata River \& Cherry Creek Ditch Co., 304 U.S. 92,110 n.12 (1988).

${ }_{125} 358$ U.S. 354 (1959). For a full treatment of the Romero case, see B. Currie, The Silver Oar and All That: $A$ Study of the Romero Case, 27 U. CHI. L. Rev. 1 (1959); Kurland, The Romero Case and Some Problems of Federal Jurisdiction, 73 Harv. L. REv. 817 (1960).
} 
tution within the meaning of 28 U.S.C. section 1331, the provision granting general federal question jurisdiction to the federal courts. ${ }^{130}$ He reasoned that such cases arise under the Constitution only in the sense that they have a constitutional sanction, i.e., in a "comprehensive, non-jurisdictional sense...."137 The four dissenters took no clear position on the meaning of this "arises under the Constitution" language in section 1331, although arguably Justices Black and Douglas would assert that admiralty matters do arise under the Constitution within the meaning of that section. ${ }^{138}$

Although the language of section 1331 under consideration in Romero is similar to that in section $1257,{ }^{139}$ the Romero case would seem to have little carry-over value relative to the problem of the scope of review under section $1257.0^{140} \mathrm{It}$ is one thing to find that a case involving the federal common law of admiralty does not present a controversy which "arises under the Constitution" so as to give general federal question jurisdiction to the federal courts in admiralty matters, but it is quite a different matter to hold that a federal common law of foreign relations, or even of admiralty, does not present rights "claimed under the Constitution" so as to give the Supreme Court power to review state court decisions on such questions. As with other statutes, when the meaning of the language is somewhat obscure, the issue for which a provision must be construed will be determinative of its interpretation, and it can hardly be controverted that the Supreme Court should have power to review state court determinations on foreign relations and admiralty questions. As a practical matter this result has in fact obtained in

\footnotetext{
136358 U.S. at 967.

${ }^{187}$ Id. at 368 .

${ }^{283}$ Arguably, Justices Black and Douglas, by incorporating into their opinions the reasoning of Judge Magruder's opinion in Doucette v. Vincent, 194 F.2d 834, 839 (1st Cir. 1952), which took a contrary position, asserted that admiralty matters do arise under the Constitution within the meaning of $\S 1331$. Id. at 388, 389. By failing to emphasize this language, Chief Justice Warren and Justice Brennan possibly have intimated that they do not. Id. at 389. Admittedly, this distinction is tenuous. Sce Currie, supra note 135 , at 59 n.327.

${ }^{130}$ The language of $\S 1331$ is: "wherein the matter in controversy ... arises under the Constitution, laws, or treaties of the United States." The language of $\S 1257$ is: "where any title, right, privilege or immunity is specially set up or claimed under the Constitution, treaties or statutes of, or commission held or authority exercised under, the United States."

${ }^{140}$ In fact, in Dyer * Sims, 341 U.S. 22, 26 (1951), Mr. Justice Frankfurter adopted the $\$ 1257$ rationale of Delaware River Comm'n $v$. Colburn in the interstate compact context. With this in mind, it would seem unlikely that his Romero opinion would control the $\$ 1257$ problem.
} 
admiralty cases, although the question of the scope of the Court's review power in such cases may never have been brought to its attention. ${ }^{141}$ The Court has simply reviewed state court determinations in admiralty cases based on non-statutory claims without adverting to this jurisdictional problem. ${ }^{142}$ The only indication that the Court has even considered this a problem in the admiralty context is dictum in the dissenting opinion of Mr. Justice Brandeis in Washington $v$. W. C. Dawson \& Co.143 Moreover, the Court of Appeals for the Third Circuit, in Jordine v. Walling, ${ }^{144}$ a 1950 case which contributed to the conflict in the circuits leading to Romero, asserted that rights claimed under the federal decisional law of admiralty are rights claimed under the Constitution within the review context of section 1257. Significantly, the Jordine opinion asserted this review power under section 1257 even though it held that rights claimed under the federal common law of admiralty do not arise under the Constitution within the meaning of section 1331. Judge Maris, writing for the court said:

It is true that the merits of a common law action upon a maritime claim, if brought in a state court, are reviewable by the Supreme Court under Section 1257 (3) of Title 28 U.S.C. because a federal question is involved. But it does not follow that such an action may be brought in a federal district court under Section $1331 . .$. Thus, while a suit for maintenance and cure involves a 'right ... claimed under the Constitution' in the sense that the Constitution made the ancient maritime law, including its doctrine of maintenance and cure, a part of our national law and is thus within the purview of Section 1257 (3), such a suit is not a case which 'arises under the Constitution' in the sense of involving a controversy as to the construction of that document and is, therefore, not within the scope of Section 1331.145

Again, there is at least as much reason to review state court determinations on questions of foreign relations in general.

Sections 1257 and 1331 differ in yet another way. In order to satisfy the jurisdictional standard of section 1331 , it is not sufficient that a right merely be set up or claimed under the Constitution, as

\footnotetext{
${ }^{111}$ See Kurland, supra note 135, at 824 n.36.

112 See Garrett v. Moore-McCormack Co., 317 U.S. 239, 245-46 (1942). Here there was a statutory Jones Act claim joined with a non-statutory maintenance and cure claim.

148264 U.S. 219, 237 n.19 (1924).

11185 F.2d 662 (1950).

${ }^{14 B} I d$. at 668 .
} 
is required by section 1257; instead, the claim must arise under the Constitution. Essentially, this has been interpreted to mean that section 1257 is satisfied if a constitutional claim is raised at any stage of the proceedings, whereas section 1331 requires that the constitutional claim be raised by the plaintiff's well-pleaded complaint. ${ }^{140}$ Thus, even if a restrictive view of the meaning of "under the Constitution" is adopted to the effect that only a claim which depends upon a construction of the Constitution comes "under the Constitution," it can. still be argued that section 1257 may be satisfied in these cases even though section 1331 is not. Under this interpretation, a plaintiff in a federal court merely asserting that his claim arises under federal decisional law for purposes of section 1331 is in most cases probably not raising a claim which substantially depends on a construction of the Constitution in any but a remote sense. On the other hand, a state court litigant who has asserted a claim governed by federal decisional law which was not followed by the state court is raising a claim which substantially depends on a construction of the Constitution when he seeks review of the state court decision under section 1257, for the Constitution itself contemplates federal common law in those areas where national uniformity and responsibility are needed. This is true, for example, with respect to admiralty, foreign relations and interstate disputes. Thus, when a state fails to follow federal law in one of these areas a constitutional right, perhaps arising under the supremacy clause, perhaps implied from the need for the federal common law itself, is immediately in issue.

Admittedly, this last distinction is somewhat tenuous, but it possibly has some value in that it serves to emphasize the difference in degree of constitutional seriousness between the issues of right to review under section 1257 and federal question jurisdiction under section 1331. In any event, Romero did not consider the question of the scope of review under section 1257 and should be accorded little weight in this matter. Moreover, the "claimed under the Constitution" language of section 1257 is subject to a broad interpretation, as the interstate disputes cases demonstrate, and such an interpretation is singularly appropriate with regard to Supreme Court review power over state court foreign relations determinations.

\footnotetext{
${ }^{148}$ Louisville \& Nashville R.R. v. Mottley, $219 \overline{\text { U.S. } 467} \overline{\text { (1911); Louisville \& Nash- }}$ ville R.R. v. Mottley, 211 U.S. 149 (1908); WrIGHT, Federal CoUrTs 52-53 (1963).
} 
Perhaps we need not quibble about the uncertain language of section 1257 in order to find a broad Supreme Court review power in this area. The Constitution provides that "the supreme Court shall have appellate Jurisdiction, both as to Law and Fact, with such Exceptions, and under such Regulations as the Congress shall make." 147 Where is the congressional exception to the Supreme Court's appellate jurisdiction with respect to foreigu relations determinations? Not surprisingly, Congress has not affirmatively made such an exception, and if there is no exception the Supreme Court must still retain the broad review power over state court foreign relations determinations which truly was its birth right. Is there any basis, then, for asserting that the Court has been deprived of such jurisdiction? The only indication in this respect derives from the venerable but suspect rationale enunciated by the Court in Durousseau v. United States ${ }^{148}$ and repeated in dictum in Ex parte $M c C a r d l e^{140}$ to the effect that an affirmative description of the Court's jurisdiction by Congress "has been understood to imply a negation of the exercise of such appellate power as is not comprehended within it."150 Although this rationale is helpful in explaining the otherwise meaningless affirmative grant of jurisdiction to the Supreme Court in the Judiciary Act, it is not persuasive that the Supreme Court was intended to be deprived of appellate jurisdiction in situations not adverted to by Congress. In particular, it is extremely doubtful that Congress intended to deny the Supreme Court jurisdiction to review state court foreign relations determinations. Arguably such a limitation on a constitutionally fundamental function of the Court would itself be unconstitutional. Moreover, it has been asserted by at least one writer that Congress has no power to curtail the appellate jurisdiction of the Court with respect to matters of law, since the exceptions and regulations power of Congress was intended to be confined to questions of fact. ${ }^{151}$ The historical data available to support this interpretation is perhaps convincing enough to require reexamination of this entire problem. ${ }^{152}$

\footnotetext{
142 U.S. Const. art. III, § 2.

${ }^{148} 10$ U.S. (6 Granch) 307 (1810).

16074 U.S. (7 Wall.) 506 (1868).

${ }^{250} \mathrm{Id}$. at 513. In Durousseau this quotation is slightly different and reads "negative on" instead of "negation of." 10 U.s. (6 Cranch) at 313 .

${ }^{18 x}$ Merry, Scope of the Supreme Court's Appellate Jurisdiction: Historical Basis, 47 MinN. L. REv. 53 (1962).

${ }^{282}$ There is some indication from the Court itself that Ex parte McCardle would
} 
There are, in short, several available rationales and some authority to support the conclusion that the Supreme Court presently has review power over all state court foreign relations decisions. It is regrettable, however, that the language of the present general review provision does not make this clear with respect to such decisions involving federal common law, and it should be changed to this end as soon as possible. In the meantime, since the desirability of such review power is self-evident, it seems likely that should the question arise the Court would uphold its appellate jurisdiction in these cases.

Having concluded that there is ample constitutional basis for a general federal common law of foreign relations binding on the states and that Erie and hopefully the problem of federal review power present no major obstacles, the next question is the scope of such a federal common law. The term "foreign relations," so far used without explanation, admittedly conjures up a variety of nebulous references. As here used, however, it is a deliberately broad term capable of encompassing the "total institutional process of [international] reciprocities and counter-reciprocities," 153 including foreign policy and foreign affairs, public international law, and even some areas traditionally characterized as private international law or domestic law. Since, as is the case with the treaty power, constitutional authority for a federal common law of foreign relations is probably substantially as broad as the need, the necessity for such a common law should largely determine its scope. The principal reasons for having a federal common law of foreign relations are to insure national uniformity and responsibility on questions affecting foreign relations. Such a federal common law, then, should include all determinations which have a sufficiently substantial effect on foreign relations to require either a national policy-making responsibility or a uniform federal rule in order to achieve effective

not stand the test of reexamination today. See Glidden Co. v. Zdanok, 370 U.S. 530, 589, 605 n.11 (1962) (dissenting opinion of Mr. Justice Douglas in which Mr. Justice Black concurred). The Durousseau rule, lowever, is only one of several possible grounds on which McCardle is suspect, and Justices Black and Douglas could have been referring to any of these. See generally Hart, The Power of Congress to Limit the Jurisdiction of Federal Courts: An Exercise in Dialectic, 66 HARv. L. REv. 1362 (1953).

${ }^{153}$ McDougal \& Lans, Treaties and Congressional-Execttive or Presidential Agreements- Interchangeable Instruments of National Policy (pt. 1), 54 YALE L.J. 181, 186 (1945). 
international implementation. In particular it would seem that it should include any determination the substantial purpose of which is to influence international affairs. There will, of course, be no bright-line distinction indicating what determinations should fit into these categories, since delicate value judgments are involved and conditions are continuously changing. The development of working distinctions here should be no more difficult, however, than in countless other areas of the law which call for fine balancing of interests. In any event, the desirability of uniformity and federal responsibility with respect to our international relations should receive greater emphasis in defining the boundaries of our federal common law of foreign relations.

Determinations which are recognized as setting foreign policy, such as act of state, must unquestionably be included in any federal common law of foreign relations. Such determinations not only have serious effects on our foreign relations as a matter of course, but they openly purport to affect foreign relations. Since the nation is internationally responsible for the actions of the states, ${ }^{154}$ it is evident that here, at least, the exigencies of foreign affairs require national responsibility. Similarly, principles of public international law, whether traditional or emerging, are by their very nature calculated to order international relations. Accordingly, questions relating to recognition of foreign judgments, sovereign and diplomatic immunity, and other areas of international law should be governed by a uniform federal common law so as to enable the nation to speak with one voice.

Significantly, the states have usually followed the federal lead with respect to determinations in these areas, notwithstanding the absence of a clearly enunciated rationale for a federal common law of foreign relations. Aside from such determinations, however, there has been considerable doubt in this regard. For example, as has been pointed out, some states do not follow the federal rule relating to recognition of foreign judgments, since they characterize this area as one involving local conflict of laws problems, not foreign relations questions. In rejecting the federal reciprocity rule, however, it is likely that the intent of these states was to influence reciprocity rule

\footnotetext{
186" [A] state may be held responsible for the decision of one of its courts which violates a treaty or international law..." JESSUP. THE USE OF INTERNATIONAL LAW 101 (1959).
} 
nations to recognize their judgments. In short, a substantial purpose of their determination to reject the Hilton rule was to influence international affairs. Such determinations require national uniformity and policy-making responsibility, and the view that they are local in nature seems unrealistic. Prior to Sabbatino the act of state doctrine was also frequently placed in the "conflicts" category, with considerable confusion resulting. ${ }^{155}$

This conflict of laws characterization with respect to foreign relations problems has had about the same loophole significance as the characterization of conflicts problems themselves as procedural rather than substantive. Confusion arises in part because of the breadth of the term "conflicts," which includes everything from jurisdiction to choice-of-law, but at least an equal share of the blame is attributable to failure to separate interstate and international conflict of laws. With a few minor exceptions, the traditional rule in the United States has regarded international and interstate conflicts law as identical, ${ }^{156}$ although in recent years this identity has begun to be challenged.157 This traditional rule has resulted in failure of the courts to focus on the high foreign policy involvement of some international conflicts cases, since once a problem is categorized as one of conflicts, state policies become controlling. Erie and Klaxon have simply compounded this confusion. The Klaxon rationale makes a great deal of sense with respect to interstate conflicts, particularly choice-of-law problems, ${ }^{158}$ but one of the major differences between international and interstate conflict of laws is that determination of some international conflicts may substantially affect foreign relations. The characterization of an internationally significant problem as one

\footnotetext{
${ }^{165}$ See Baade, The Legal Effect of Cuban Expropriations In the Uniled States, 1963 Duke L.J. 290, 300-01; Henkin, The Foreign Affairs Power of the Federal Courts: Sabbatino, 64 Colum. L. REv. 805, 809-11 (1964); Comment, The Act of State Doctrine -Its Relation to Private and Public International Law, 62 CoLUM. L. REv. 1278 (1962). ${ }^{260}$ See RESTATEMENT, Confict of LAws $\$ 2$ (1934); Yiannopoulos, Wills of Movables in American International Conflicts Law: A Critique of the Domiciliary "Rule," 46 CALIF. L. REv. 185 (1958). "Very little indication of a conscious distinction between interstate and international contacts can be found in American judicial decisions or legal literature." Id. at 187.

${ }^{187}$ See DuBois, The Significance in Conflict of Laws of the Distinction Between Interstate and International Transactions, 17 MiNN. L. REv. 361 (1933); Ehrenzweig, Interstate and International Conflicts Law: A Plea for Segregation, 41 MiNN. L. REv. 717 (1957); Yiannopoulos, supra note 156; Comment, supra note 155, at 1296.97.

${ }^{158}$ See Cavers, The Changing Choice-of-Law Process and the Federal Courts, 28 LAW \& CONTEMP. PROB. 732 (1963); Cavers, Change in Choice-of-Law Thinking and its Bearing on the Klaxon Problem, in ALI Study of THE Division of JuRisdiction Be. tween State and Federal Courts 154 (Tent. Draft No. 1, 1963).
} 
of conflicts simply begs the question, then, and such characterization should not necessarily be controlling on the issue of whether federal foreign relations law should govern resolution of the problem. In fact, it could be argued that any international conflicts case ipso facto so involves United States foreign relations that it should be controlled by federal common law, thus sharply limiting Klaxon. It is probable, however, that any such blanket rule would be undesirable, since most such cases probably do not involve foreign relations in any meaningful way. In particular, the very important area of choice-of-law may not be a suitable subject for federal common law even in the international conflicts cases, since there are compelling reasons for encouraging the states individually to determine whether they have an interest in applying their laws.159 There may, of course, be areas of international choice-of-law so involved with the federal foreign relations interest as to require national control. For example, suppose that a state refuses to give effect to a racially mixed marriage lawfully consummated in a foreign country, asserting the applicability of a local law or public policy prohibiting such marriages. Would this situation justify a federal common law conflicts rule based on the exigencies of foreign relations? ${ }^{160}$ In this and other situations which could be imagined the national foreign relations interest would be in conflict with a state's policy on domestic matters. Perhaps the result in such situations should depend on a balancing of these competing interests, taking into account the seriousness of the threat to foreign relations and the interest of the state in having its policy applied. In any event, although it would probably be wrong to limit Klaxon with respect to international conflicts in general, international conflict of laws cases should be subject to federal scrutiny in order to insure that individual state policies do not needlessly sacrifice the nation's foreign relations interests.

Taking this rationale one step further, could a federal common law of foreign relations be justified in any case in which there is disagreement between the national government and a state with respect to an essentially domestic question which incidentally has a substantial effect on foreign relations? The question, of course, is

\footnotetext{
180 See B. Currie, Selected Essays on the Conflict of Laws (1963); B. Currie, The Disinterested Third State, 28 LAw \& Contemp. Prob. 754 (1963).

${ }^{200}$ If such a state law were held to deny equal protection, this rationale could provide an additional basis for decision.
} 
one of degree, and words like "substantial" and "domestic" have no definite meaning. It is certainly true, however, that the realities of today's world do not permit a sharp distinction between domestic and foreign relations questions, for in our present era of rapid transportation and communication domestic policy is becoming increasingly significant with respect to foreign relations. For example, domestic racial discrimination may affect our relations with mucl of Africa. It is becoming increasingly unrealistic, then, to attempt to separate domestic and foreign affairs. In fact, arguments for the necessity of a federal common law of foreign relations could be verbalized almost identically with respect to both recoguition of foreign judgments and the race problem, for both have substantial effects on our foreign relations. Yet because race problems in general largely do not directly involve international contacts and are thus usually characterized as domestic, the foreign relations power is not generally invoked in the United States with respect to these problems either as a source of power by which to invalidate state laws or as a source of power for federal law, although the effect on foreign relations is often adverted to as an additional reason for a particular course of action. Of course, this failure to invoke the federal foreign relations power is at least partly attributable to the existence of other clearly applicable sources of federal constitutional power to deal with such problems, and certainly it is attributable to the great domestic interest regarding these problems. This failure, however, perhaps also reflects uncertainty as to the scope of the federal foreign relations power and a general reluctance to assert this power in situations in which a problem is characterized as domestic or internal, despite the problem's profound effect on foreign relations. Such characterization, usually made on the basis of whether a problem involves more or less direct international contacts, is largely question begging and results in too narrow a view of the foreign relations power. Undoubtedly there comes a point when the effect of a determination on foreign relations is so slight in relation to the domestic purpose served that the foreign relations power should not be invoked, but the decision to this effect should consciously involve evaluation of the impact of the determination on foreign relations and the need for a uniform federal rule in light of that impact The general reluctance to utilize the foreign relations power in situations involving problems characterized as domestic, yet 
substantially affecting foreign affairs, should be abandoned. Thus, the federal foreign relations power must be formulated with sufficient clarity and breadth to insure its recognition and application by the courts whenever the need is present, notwithstanding traditional and sometimes sterile characterizations. In so doing, federal control over state policies will be reinforced to the extent that the exigencies of foreign relations demand.

Even in areas in which there is undisputed federal judicial control over foreign relations, there may still be some room for local variations. For example, in an interesting footnote in Sabbatino the Supreme Court somewhat qualified its statement that act of state problems are exclusively federal. The Court said:

At least this is true [that act of state problems are exclusively federal] when the Court limits the scope of judicial inquiry. We need not now consider whether a state court might, in certain circumstances, adhere to a more restrictive view concerning the scope of examination of foreign acts than that required by this Court. ${ }^{161}$

This cautious statement possibly indicates that some state variations with respect to the act of state doctrine would be permissible; and, if variations are permissible in this area, possibly the same result would obtain with respect to other matters governed by a federal common law of foreign relations. At first blush little danger is apparent in such permissiveness so long as there is a federal framework within which the states must remain. In the admiralty area, for example, the Court has permitted some latitude on the part of the states with respect to essentially local matters. Thus, in Wilburn Boat Co. v. Fireman's Fund Ins. Co., ${ }^{162}$ where the facts of the case made it a matter of local concern, the Court allowed state policies to govern the effect of warranties in a marine insurance policy. Yet even in the admiralty context, because of the difficulty in formulating standards as to what matters are local, Wilburn has been criticized as tending to destroy the essential uniformity required with respect to admiralty matters in general.103 Moreover, the federal common law of admiralty, unlike that of foreign relations, largely

101376 U.S. at 425 n.23.

102348 U.S. 310 (1955).

${ }^{103}$ See Gilmore \& Black, The LAw of Admiralty 44-45, 61-63 (1957); D. Currie, Federalism and the Admiralty: "The Devil's Own Mess," 1960 Sup. CT. Rev. 158, 216-21. 
arises on a territorial rather than a substantive jurisdictional basis. ${ }^{104}$ As a result, because of its less restrictive jurisdictional basis, there may be significantly more room for local variations in admiralty.

On closer inspection, such latitude in the context of the act of state doctrine carries hidden dangers. In formulating its rule on act of state, the Court in Sabbatino not only limited the scope of judicial inquiry but also pointed out areas in which it would presumably feel free to inquire into foreign acts. Specifically, the limitation on the scope of judicial inquiry into a foreign act of state was predicated on "the absence of a treaty or other unambiguous agreement regarding controlling legal principles."165 Yet if the Court's footnote is read literally, it intimates that perhaps a state court wishing to take a more restrictive view concerning the scope of judicial inquiry into foreign acts need not follow such authorities. Admittedly, limiting the scope of judicial inquiry into foreign acts of state is probably the more important limitation with respect to preventing international friction, but it would seem that the extent of such limitation also requires a nationally uniform solution. Regardless of whether the footnote in fact permits this much license, it indicates the dangers of attempting to leave latitude to the states in an essentially federal area.

Discussion thus far has related to the necessity for a federal common law of foreign relations simply as a prerequisite for effective federal control over foreign relations questions. Undoubtedly, though, the scope of a federal common law of foreign relations will also be affected by the limitations on the judicial branch vis-à-vis the other branches of government in setting foreign policy. ${ }^{108}$ That is, although a particular question may be said to be controlled by federal common law in the sense that it will not be left to individual state determination, this does not necessarily mean that a positive federal judicial rule will be promulgated or that such a rule will take precedence over determinations by other branches of the federal government. Constitutional acts of Congress and treaties, for example, will continue to bind the courts. Moreover, the federal executive has a substantial sphere of control with respect to foreign

"os Sce GILMORE \& BLACK, op. cit. supra note 163, at 18-47.

${ }^{100} 376$ U.S. at 428.

${ }^{200}$ See generally JAFfe, Judicial Aspects of Foreign Relations (1933); Wrigut, The Control of american foreign Relations (1922). 
relations, and at least in some situations the executive branch is probably better suited for formulation of foreign policy than are the courts. Past experience has shown that the courts are acutely sensitive to this role of the executive in foreign affairs and that they will generally defer to executive determinations in this area. ${ }^{167}$ Although such a policy of deference could be taken too far, certainly it is proper for the courts to be aware of their own limitations in formulating rules of decision. In any event, the scope of a federal common law of foreign relations will necessarily be limited by the foreign relations powers of the other branches of the federal government. Thus, to argue for a federal common law of foreign relations is not necessarily to argue for final judicial dominance on foreign policy questions arising in the courts. Rather it is simply to recognize that in the absence of policy formulations by the other branches of the federal government, realistic federal control over individual state determinations in this area can be achieved only through such a law.

In summary, the federal common law of foreign relations must be broadly conceived, using as a guideline the necessity for federal control of foreign relations. One of the principal shortcomings of the past has been too narrow a view of the scope of this federal common law. Thus, we have failed to achieve federal control over certain determinations which substantially affect our foreign relations. Nevertheless, future judicial creativeness in this area must continue to be tempered with an awareness of the limitations of the judicial branch in the formulation of foreign policy.

\section{IV}

Foreign ReLATIONS AND FEderal Question JURISDiction

Many of the problems so far discussed are attributable to the dual nature of our court system. Cases involving foreign relations questions requiring a uniform national rule commonly arise in both state and federal courts, and since such questions are essentially federal in nature, it is necessary that a clear rationale be formulated under which the state and federal courts will be compelled to follow the same substantive federal standards. These problems could conceivably be avoided completely by vesting jurisdiction over foreign relations cases exclusively in the federal courts, thus eliminating the

\footnotetext{
${ }^{107}$ See authorities cited note 49 supra.
} 
opportunity for individual state responses in this area. Leaving aside the difficult question of where the jurisdictional line would be drawn under such a scheme, however, a major premise upon which our dual court system is based is that there is value in having concurrent state jurisdiction over most cases involving federal problems. ${ }^{168}$ Consequently, so long as there is a federal common law of foreign relations binding on the state courts, it would probably be better to retain state court jurisdiction over cases involving foreign relations questions. It would seem, however, that there should also be available in such cases a federal forum of original jurisdiction. This would enable the federal courts to set an example for state court treatment of such questions, and would facilitate the growth of a federal common law in this area. ${ }^{160}$ Nevertheless, at present it is not clear that all such questions could initially be presented in a federal court.

Constitutional and statutory provisions for federal jurisdiction in situations likely to involve foreign relations questions are numerous enough to unmistakably demonstrate a constitutional and congressional intent that questions.likely to affect the nation's foreign relations be originally cognizable in the federal courts. ${ }^{170}$ Unquestionably many cases involving foreign relations questions could be initiated in the federal courts under one or another of these statutory provisions; others would find their way into the federal courts under the general diversity provisions of 28 U.S.C. section 1332. Absent diversity or applicability of one of these special provisions, however, there is some doubt whether a federal forum would be available in the first instance in every case involving a question affecting foreign relations. This apparent defect in federal jurisdiction is largely a result of the fragmented congressional approach to the problem of original jurisdiction in foreign relations cases, with its accompanying inevitable failure to advert to all possible situations in which such questions could arise. A strong argument might be made that this gap in original federal jurisdiction was largely filled by the addition of general federal question jurisdiction under the Judiciary Act of

\footnotetext{
${ }^{108}$ See Hart, The Relations between State and Federal Law, 54 ColuM. L. REv. 489, 506-08 (1954).

${ }^{100}$ Such federal court availability might also be desirable in order to insure adequate procedural standards in foreign relations cases. See id. at 508 .

${ }^{170}$ See U.S. CoNST. art. III, § 2; 28 U.S.C. $\$ \S 1251,1333,1350-51$ (1958).
} 
1875.171 This jurisdictional grant is now contained in 28 U.S.C. section 1331 (a), ${ }^{172}$ which currently provides:

The district courts shall have original jurisdiction of all civil actions wherein the matter in controversy exceeds the sum or value of $\$ 10,000$, exclusive of interest and costs, and arises under the Constitution, laws, or treaties of the United States.

Do cases involving questions governed by a federal decisional law of foreign relations, as opposed to those involving foreign relations questions controlled by a federal statute or treaty, arise "under the Constitution, laws, or treaties of the United States" within the meaning of section 1331? If they do, then almost any case involving a foreign relations problem would be initially cognizable in the federal courts, subject only to the requirements pertaining to jurisdictional amount, personal service, venue and pleading.

As has been pointed out, Mr. Justice Frankfurter's opinion in Romero v. International Terminal Operating Co. ${ }^{173}$ rejected the idea that cases arising under the federal common law of admiralty arise under the Constitution or laws of the United States within the meaning of this provision. ${ }^{174}$ Because of the kinship between a federal decisional law of foreign relations and the federal common law of admiralty, this decision has obvious relevance with respect to federal jurisdiction over cases involving foreign relations questions under section 1331. It is doubtful that many claims asserted under federal decisional law, either of admiralty or foreign relations, would be interpreted today as arising under the Constitution within the meaning of section 133I. Cases involving questions governed by a federal decisional law of foreign relations, however, may well arise under the laws of the United States within the meaning of that section, even though admiralty cases apparently do not under Romero. In admiralty cases the federal district courts already have general jurisdiction under 28 U.S.C. section 1333. The difficulty dealt with in Romero

${ }^{171}$ Act of March 3, 1875, § I, 18 Stat. 470.

272 "The modifications of language to be found in the present version of this Act, 28 U.S.C. $\S 1331$, were not intended to change in any way the meaning or content of the Act of 1875." Romero v. International Terminal Operating Co., 358 U.S. 354, 359 n.5 (1959).

178 Id. at 354.

${ }^{27}$ The opinion also created some doubts, for the most part apparently unfounded, as to whether maritime claims based on acts of Congress were included in section 1331 . See Wetherington, Jurisdictional Bases of Maritime Claims Founded on Acts of Congress, 18 U. MIAMI L. REv. 163 (1963). 
was simply whether the "law side" of the federal district courts was also available to admiralty litigants-largely a conceptual problem with the right to a jury trial being the real issue. This is quite a different problem from that faced in foreign relations cases where at least some causes currently have no basis for original federal jurisdiction unless section 1331 is applicable.

In light of this fundamental difference, much of the reasoning of the majority in Romero would seem inapplicable with respect to foreign relations cases. For example, the argument that the Judiciary Act of 1875 was not intended to confer jurisdiction in admiralty cases because the federal district courts already had general admiralty jurisdiction at the time of its enactment ${ }^{175}$ would seem to prove nothing with respect to cases involving foreign relations questions. Similarly, the argument that there was no indication that the act intended silently to change the traditional procedure in admiralty cases so as to authorize jury trials ${ }^{176}$ is inapplicable here. Moreover, much of the majority's concern in Romero was over the prospect of interfering with the traditional role of the states in admiralty cases as manifested by Congress in the "saving-clause," 177 and there is no such clause with respect to foreign relations cases. Even accepting Mr. Justice Frankfurter's argument that admiralty and maritime cases constitute a distinct class of article three cases which were intended to be excluded from the provision of the Judiciary Act of 1875 endowing the federal courts with jurisdiction over cases arising "under the Constitution, laws or treaties of the United States,"178 this would not preclude a different finding with respect to foreign relations cases. Unlike the admiralty power, the federal judiciary's power over foreign relations cases does not derive from a provision of article three clearly distinct from the arising under power. Rather, it would seem to be implied from the intent of the article as a whole. Thus, there appears to be no justification for applying

\footnotetext{
276358 U.S. at $368-69$.

270 Id. at 369.

${ }^{277}$ Id. at 371-75. The "saving clause" is a provision of the Judiciary Act of 1789, preserving the role of the states in the administration of maritime law. Act of Sept. $24,1789, \S 9,1$ Stat. 76 . This provision is now substantially contained in 28 U.S.C. $\S$ 1333 (1958).

${ }^{178} 358$ U.S. at 360-68. Similar arguments were made in Paduano v. Yamashita Kisen Kabushiki Kaisha, 221 F.2d 615, 618 (2d Cir. 1955); Jordine v. Walling, 185 F.2d 662, 668 (3d Cir. 1950).
} 
this argument to exclude cases arising under a federal decisional law of foreign relations from section 1331.

In short, none of the arguments of the majority in Romero demonstrate that cases involving foreign relations questions are not to be included within the scope of section 1331. Moreover, the facts that Romero was decided five to four on this point with respect to admiralty cases and that several members of the Romero majority are no longer on the Court, ${ }^{179}$ further strengthen the conviction that Romero will not preclude a broad interpretation of section 1331 perhaps to include cases arising under federal decisional law in general, ${ }^{180}$ at least in areas other than admiralty, and particularly to include those involving foreign relations questions. The federal decisional law of foreign relations has in reality just begun to be clarified, and it is doubtful whether the draftsmen of the Judiciary Act of 1875 even understood cases involving claims based upon such law. This act did, however, evidence a general congressional intent that matters of federal significance be initially cognizable in the federal courts. It would seem, then, that cases arising under a federal decisional law of foreign relations should be embraced by the jurisdictional grant now contained in section 1331.

One of the principal difficulties involved in interpreting section 1331 to include cases arising under a federal decisional law of foreign relations would be the resulting day-to-day jurisdictional determinations which would be necessary regarding what questions have sufficient foreign relations potential to justify federal question jurisdiction. The majority in Romero adverted to this problem in the admiralty context, ${ }^{181}$ and no doubt such an interpretation would also require subtle determinations as to "the boundaries of state and federal competence"182 in the foreign relations area. In many cases, such as those involving act of state problems, there should be little doubt that federal law controls, and it is precisely in these areas that access to a federal forum is most needed. Even in the doubtful areas, perhaps the difficulties of determining such questions would be more than offset by the desirability of having the boundaries of state and federal competence clarified with respect to foreign relations. In any event, it may be worth major adjudicatory difficulties

\footnotetext{
17" Justices Frankfurter-the author of the Court's opinion in Romero-and Whittaker have been replaced by Justices Goldberg and White.

${ }^{180}$ See Kurland, supra note 135 , at 827-33.

101358 U.S. at $375-76$.

282 Id. at 376 .
} 
to insure that all foreign relations questions of national import can be presented in a federal forum in the first instance.

Another difficulty in this respect is the rule under section 1331 requiring that the federal question be raised by the plaintiff's wellpleaded complaint. ${ }^{183}$ This rule, of course, would not prevent a broad interpretation of section 1331 to include cases arising under a federal decisional law of foreign relations, but it would exclude cases involving foreign relations questions which could not be legitimately raised in the complaint. Since many areas governed by the federal law of foreign relations involve matters primarily of defense, as for example act of state and sovereign and diplomatic immunity, ${ }^{184}$ this rule could be a serious stumbling block to utilization of section 1331 to provide an initial federal forum in foreign relations cases. The rule has been generally criticized on the ground that it is merely a conceptualistic requirement which results in the federal courts taking jurisdiction in many situations in which there is no real federal question and denying it in others where there is such a question. ${ }^{185}$ In view of the fact that many foreign relations questions arise only by way of defense, this criticism would seem particularly applicable with respect to foreign relations cases. Moreover, the importance of an initial federal forum in such cases is even greater than in the usual federal question case. Hopefully, either by liberally interpreting this rule in foreign relations cases or by abolishing it altogether, it will be possible to avoid the otherwise anomalous consequences.

Since jurisdiction in Banco Nacional de Cuba v. Sabbatino ${ }^{186}$ was posited by the Second Circuit on diversity, this decision has shed little light on the scope of section 1331, except perhaps to point out that the possibilities of jurisdiction under that section in foreign relations cases are generally overlooked or avoided. The Second Circuit declined to determine whether federal question jurisdiction was also present in Sabbatino, even though the complaint had al-

\footnotetext{
${ }^{188}$ Louisville \& Nashville R.R. v. Mottley, 211 U.S. 149 (1908); WRIGHT, op. cit. supra note 146 , at $52-53$.

${ }^{184}$ At least one court has classified the Filton reciprocity doctrine as a matter of defense. Gull v. Constam, 105 F. Supp. 107,109 (D. Colo. 1952), 38 CorNell L.Q. 423 (1953). The issue there. however. was simply whether the complaint stated a cause of action.

${ }^{185}$ See Wright, op. rit. supra note 146, at 52; Comment, Proposed Revision of Federal Question Jurisdiction, 40 ILL. L REv. 387.397 (1945). ${ }^{180} 307$ F.2d 845 (2d Cir. 1962), rev'd, 376 U.S. 398 (1964).
} 
leged jurisdiction under both section 1331 and 1332.187 The Supreme Court in its consideration of the case likewise expressly declined to determine whether federal question jurisdiction existed, ${ }^{188}$ since it decided that there was an adequate jurisdictional ground present and that federal law governed in any event.

If section 1331 is interpreted to include cases arising under a federal decisional law of foreign relations, it is unlikely that the federal courts will be overwhelmed by a flood of such actions under that section, and such an interpretation would materially strengthen federal control over resolution of the foreign relations questions which arise in the courts. Regardless of the ultimate interpretation of section 1331, however, consideration should be given to a new general provision clearly articulating original federal jurisdiction in all foreign relations cases.

Foreign Relations and the Police Power of the States

It is a generally accepted constitutional principle that the states have no independent foreign affairs power as such. ${ }^{189}$ They do, however, have primary responsibility for regulation of many domestic affairs, which they accomplish through the exercise of what may loosely be termed their police power. In theory this distinction between foreign and domestic affairs is plain, but in practice the distinction is often extremely subtle and elusive. Increasingly today, the exercise of the state police power with respect to what have traditionally been considered purely domestic matters can have a profound effect on our foreign relations. The race problem affords an obvious example, but there are many less apparent problem areas traditionally characterized as "domestic" in which state action also can have a significant effect on foreign relations. Thus, in order to insure implementation of foreign policy at the national level, it is imperative that there be substantial federal control over independent

297307 F.2d at 852 .

188 "Although the complaint in this case alleged both diversity and federal question jurisdiction, the Court of Appeals reached jurisdiction only on the former ground.... We need not decide, for reasons appearing hereafter, whether federal question jurisdiction also existed." 376 U.S. at 421 n.20.

${ }^{180}$ See, e.g., United States v. Pink, 315 U.S. 203, 233 (1942); United States v. Belmont, 301 U.S. 324, 331 (1937); Henkin, The Treaty Makers and the Law Makers: The Law of the Land and Foreign Relations, 107 U. PA. L. REv. 903, 936 (1959). 
state action taken pursuant to the police power which affects foreign relations.

The generally accepted techniques for achieving federal control over foreign relations which were examined previously, i.e., the treaty and executive agreement powers, the legislative powers of Congress, and the executive suggestion, are as limited with respect to control of state legislative and executive action as they are with respect to control of state judicial action affecting foreign relations, and largely for the same reasons. In fact, there may even be greater reluctance to interfere with state exercise of the police power because of the "states rights horribles," which are more clearly presented in the context of state legislative or executive action. Particularly is this true regarding use of the executive suggestion, which a cursory but conscientious search of the authorities indicates has never been used to request action contrary to an applicable state statute affecting foreign relations. To some extent, of course, the situation calls for broader conception and more active exercise of the congressional and executive foreign relations powers, but again, the problem seems particularly amenable to judicial resolution. Since the foreign relations power is vested exclusively in the national government by the Constitution, control of independent state legislative or executive action in this area could be achieved rapidly and effectively by judicially declaring any state determination adversely affecting foreign relations unconstitutional, either as an invasion of the federal foreign relations power or as in conflict with pertinent, constitutionally authorized federal common law. ${ }^{190}$ Thus, the federal decisional law of foreign relations would be employed to limit the exercise of the state police power in the same manner in which it is used to control state judicial determinations which affect foreign relations.

That constitutionally authorized federal common law must take precedence over any type of state action in a given area is simply an obvious prerequisite to effective federal control in that area. The admiralty cases, for example, constitute clear authority for the proposition that constitutionally authorized federal common law prevails over conflicting state statutes as well as judicial decisions. Thus, in Southern Pac. Co.v. Jensen ${ }^{191}$ the Supreme Court held that the New

${ }^{100}$ In so doing, of course, the courts should proceed with caution, recognizing that the judiciary plays only a secondary role in the conduct of foreign affairs.

101244 U.S. 205 (1917). 
York Workmen's Compensation Act could not constitutionally be applied to a maritime claim where it would have interfered with the essential uniformity of the federal decisional law of admiralty. Although Jensen has proved rather ill-starred because of the difficulty in drawing the line between admiralty matters requiring federal uniformity and those which do not, ${ }^{192}$ the principle for which it stands has been generally accepted. ${ }^{193}$ A fortiori the constitutionally authorized federal decisional law of foreign relations should likewise serve to limit legislative exercise of the state police power. Unlike the situation with respect to admiralty matters, the foreign relations power is vested exclusively in the federal government by the Constitution, and there is no "saving clause" in this area or any constitutional justification for such a clause. It would seem, for example, that the California statute which rejected the Hilton reciprocity rule with respect to recognition of foreign judgments ${ }^{194}$ is unconstitutional and should be subordinated to the federal rule, since this exercise of state police power, for reasons previously discussed, interferes substantially with the essential national uniformity on this foreign relations matter. The same result should follow in a case involving an executive exercise of the state police power which conflicts with some aspect of the federal common law of foreign relations, since the need for federal responsibility and uniformity remains the same.

Even in the absence of a specifically applicable federal decisional rule of foreign relations, independent state action taken pursuant to the police power which affects foreign relations should be subject to constitutional scrutiny. The Constitution as a whole contemplates that the foreign relations power is to be exclusively federal, and state action which interferes with necessary federal responsibility or uniformity in this area must yield. The preemption doctrine which is utilized in the interstate commerce cases, although reflecting a slightly different rationale from that of a controlling federal common law or constitutionally exclusive federal responsibility, ${ }^{195}$ is in essence a means of achieving federal control over state exercise of the police power in areas thought to require federal uniformity and responsibility; as such, it lends some credence to a parallel solution

102 Baer, Admiralty Law of the Supreme Court 70-91 (1963).

${ }^{108}$ See, e.g., Washington v. W. C. Dawson \& Co., 264 U.S. 219 (1924); Knickerbocker Ice Co. v. Stewart, 253 U.S. 149 (1920).

104 See statute cited note 60 supra.

${ }^{108}$ See cases cited note 46 supra. Cf. Dean Milk Co. v. City of Madison, 340 U.S. 349 (1951); Southern Pac. Co. v. Arizona, 325 U.S. 761 (1945). 
in the at least equally sensitive foreign relations area. ${ }^{198}$ In any event, regardless of the rationale, the federal foreign relations power should take precedence over any exercise of the state police power.

Once it is established that federal power in this area is supreme, the difficult task of distinguishing between a valid state exercise of its police power and an encroachment on the federal foreign relations power remains. Generally speaking, the federal power should be invoked in situations requiring federal uniformity or responsibility for effective conduct of foreign relations, and in particular it should be invoked whenever the very purpose of the state action in question is to affect foreign relations. On the contrary, when the effect of the state action on foreign relations is slight in relation to the domestic purpose served, the federal power should not be invoked. As is the case with most other problems of federalism, the test here will involve a balancing of interests, and there will be few absolutes. ${ }^{197}$ It would seem, however, that with respect to many problems traditionally characterized as "domestic" or "internal," the need for federal uniformity and responsibility has not received sufficient weight. In fact, to date the test with respect to such problems has been largely confined to inquiring whether the independent exercise of the state police power entered the forbidden area of negotiation with a foreign power or violated a treaty. Thus, the full potential of the federal foreign relations power as a check on the state police power has not been realized. Matters which should be closely controlled pursuant to a broadly conceived federal foreign relations power have received federal control, if at all, only through the exercise of other constitutional powers, as for example the limited protection of aliens so far achieved largely under the equal protection clause. ${ }^{188}$ Undoubtedly the equal protection clause is applicable in this area, but the federal foreign relations power should also be involved in view of the fact that state regulation with respect to aliens can significantly affect our foreign relations, often without

\footnotetext{
${ }^{100}$ This is particularly true with respect to the notion of preemption resulting from congressional silence. See Leisy v. Hardin, 135 U.S. 100, 109 (1890); Forkosch, CONSTITUtional Law 234-38 (1963).

107 Witness, for example, the innumerable state-federal conflicts arising from the federal commerce power.

${ }^{208}$ See, e.g., Takahashi v. Fish \& Game Comm'n, 334 U.S. 410 (1948); Truax v. Raich, 239 U.S. 39 (1915); Bayitch Aliens in Florida, 12 U. MIAMI L. Rev. 129, 132.38 (1958); Note, Constitutionality of Legislative Discrimination Against the Alien in His Right to Work, 83 U. PA. L. REv. 74 (1934).
} 
implementing any justifiable domestic interest. Treatment of aliens and other problems traditionally characterized as "internal" at least call for evaluation of the effect of state action in these areas on foreign relations, the need for a uniform federal rule in the light of that effect, and perhaps then a balancing of this need against any legitimate state interest involved. The exigencies of today's world demand that the federal foreign relations power come of age as a power in its own right. So far, however, the few Supreme Court cases which have dealt with the difficult problem of where to draw the line between a valid state exercise of its police power and an encroachment on the federal foreign relations power have tended to sanction too broadly state policies the implementation of which seriously affect foreign relations.

Holmes $v$. Jennison, ${ }^{199}$ decided in 1840 , was one of the earliest cases to grapple significantly with this problem. ${ }^{200}$ The case involved a resident of Quebec who fled to Vermont after allegedly committing murder in the then British Province of Lower Canada. Subsequently, he was indicted in the District of Quebec. The Governor of Vermont ordered his arrest and extradition to Quebec, apparently pursuant to a private agreement with Canadian authorities. On habeas corpus the Supreme Court of Judicature of Vermont upheld the Governor's action, and the case was taken to the Supreme Court of the United States under a writ of error. At the time, there was no United States extradition treaty in force with Britain. In fact, fourteen years earlier a previous Governor of Vermont had refused a similar request from Canadian authorities seeking to extradite two British soldiers who were wanted in Canada for robbery, apparently

10039 U.S. (14 Pet.) 540 (1840).

${ }^{200}$ Another early case, People v. McLeod, 25 Wend. 483 (N.Y. Sup. C.. 1841), presented a situation of state-federal conflict with respect to foreign relations but never reached the Supreme Court. The $M c L e o d$ case grew out of the retaliatory raid on the steamer Caroline on the American side of the Niagara River in 1837 by a Canadian force. Alexander McLeod was subsequently arrested and prosecuted for murder in New York for taking part in the raid. The British government demanded his release on the ground that the raid was a "public act of persons in Her Majesty's service, obeying the order of their superior authorities." There was extensive diplomatic correspondence over the incident, some of it concerned with the power of the federal government to interfere with the states in such situations. Although Mcleod was denied habeas corpus by the New York Supreme Court, he was ultimately acquitted. See 26 Wend. 663 (1841) (Review of the opinion of Judge Cowen in the McLeod case by Judge Tallmadge of the Superior Court of the City of New York); Bishop, Cases on International Law 213 n.5 (2d ed. 1962); Comment, supra note 155, at 1296 n.123. 
basing his refusal on a contrary national policy. At the time of this earlier incident the Governor had written to Secretary of State Clay, bringing the extradition request to his attention and stating his willingness to abide by the Secretary's decision. In reply, Secretary Glay pointed out that the Ganadian extradition request could not be complied with, since the British-American extradition treaty had expired and was a subject of negotiation between the two countries.

The Supreme Court, in one of those rare decisions in which a majority of the Court could not agree on a course of action, finally dismissed the writ of error for want of jurisdiction. ${ }^{201}$ Significantly, though, five of the eight justices taking part in the decision felt that Vermont could not constitutionally enter into an agreement such as the one relied upon by the Governor under the exercise of its police power, since such an agreement with a foreign power was a matter within the exclusive province of the federal government. In a masterpiece of judicial craftsmanship, Chief Justice Taney wrote an opinion, ${ }^{202}$ concurred in by Justices Story, McLean and Wayne, in which he espoused a broad federal supremacy over foreign relations stemming from the Constitution as a whole, rather than merely from specific prohibitions on the states, and in which he made it clear that the agreement in question went substantially beyond the permissible limits within which the state police power may be exercised. He said:

The state does not co-operate with a foreign government, nor hold any intercourse with it, when she is merely executing her police regulations. But in the case of Holmes, it is otherwise. The state acts, not with a view to protect itself, but to assist another nation which asks its aid. Holmes is not removed from the state of Vermont, as a man so stained with crimes as to render him unworthy of the hospitality of the state; but he is delivered up to the Canadian authorities, as an act of comity to them. This is not the exercise of a police power, which operates only upon the internal concerns of the state, and requires no intercourse with a foreign country, in order to carry it into execution; it is the comity of one nation to another, acting upon the laws of nations, and determining, for itself, how far it will assist a foreign nation in bringing to punishment those who have offended against its laws. ${ }^{203}$

20139 U.S. (14 Pet.) at 598.

${ }^{202}$ Id. at 561 .

208 Id. at 569 . 
Now, it is very evident, that the councils of the general government and of the state may not always agree on this subject. The decision of the one may stand in direct opposition to the decision of the other. How can there be a concurrent jurisdiction in such a case? They are incompatible with each other, and one must yield. And it being conceded on all hands, that the power has been granted to the general government, it follows, that it cannot be possessed by the states; because its possession on their part would be totally contradictory and repugnant to the power gxanted to the federal government. ${ }^{204}$

In a separate opinion ${ }^{205} \mathrm{Mr}$. Justice Catron took a somewhat narrower view, arguing that if a demand for the extradition of Holmes had in fact been made by Canadian authorities the Governor's action would have amounted to an agreement by Vermont with a foreign power which would have been forbidden in the absence of congressional consent by article one, section ten of the Constitution. Since he assumed that no such demand had been made by Canadian authorities, however, he felt that there had been no agreement and consequently that no provision of the Constitution had been violated. The remaining three justices participating in the decision wrote separate opinions which largely took the position that the Constitution did not automatically prohibit this type of agreement, at least in the absence of a controlling treaty. ${ }^{206}$ Eventually, after examining the many opinions of the justices of the Supreme Court, the Supreme Court of Judicature of Vermont was convinced that authority to extradite Holmes did not exist and ordered his release. ${ }^{207}$

In restrospect the Holmes case hardly seems as difficult as all this. Chief Justice Taney appears to have been clearly correct, both in asserting a broad, exclusive federal power over foreigu relations and in categorizing Vermont's action as an improper exercise of its police power. In light of the history of dealing with such matters by treaty and the contemporaneous federal policy of not allowing extradition in the absence of a treaty, how can there be any doubt? If the United States is to be effective in its conduct of foreign relations

\footnotetext{
206 Id. at 575 .

${ }^{206}$ Id. at 594 .

${ }^{200} \mathrm{Mr}$. Justice Baldwin, though, denied even the competency of the treaty power to "prevent the expulsion of a fugitive from justice from the territory of a state. pursuant to its laws, or the general authority vested in its executive or other appropriate officers, to administer and enforce its regulations of internal police." Id. at 586. 207 Id. at 598.
} 
certainly there must be a supreme federal authority capable of dictating a uniform policy throughout the nation on matters of international significance. Thus, a holding to the effect that international extradition is within the competence of the states, even in the absence of a current treaty, would have destroyed the bargaining position and capacity to compel uniformity necessary for an effective exercise of the treaty power in this area. There was some evidence, in fact, that Canadian authorities had refused to extradite persons to this country. ${ }^{208}$ As is the case with respect to recognition of foreign judgments, then, here again we find a state thoughtlessly impairing the federal bargaining position by taking an approach largely ineffective on the merits.

This is not to say that Vermont has no interest which could have been served by the exercise of her police power in this situation, as Chief Justice Taney intimated. Vermont does have an interest in protecting her citizens, an interest which to some extent can be effectuated by extraditing persons accused of crime in foreign countries. Since the nation as a whole has an overriding interest in concluding such agreements with foreign nations, however, an interest not only in extraditing persons from this country but also in insuring that persons accused of crime in this country who have fled to foreign countries will be delivered up to American authorities, this exercise of the police power interfered too substantially with the federal foreign relations power. Thus, the balance in Holmes was necessarily struck in favor of the greater national interest.

It should be noted, however, that even Chief Justice Taney's opinion was largely preoccupied with simply ascertaining whether the state action involved had entered the forbidden area of negotiation with a foreign power or had infringed the treaty powver. There was still no realistic appraisal of the possibility of utilizing the federal foreign relations power as a constitutional check on exercises of the state police power which affect foreign relations but do not constitute negotiation with a foreign country or violations of the treaty power.

In Blythe v. Hinckley, ${ }^{209}$ decided in 1901, the Supreme Court again considered the problem of distingnishing between a valid exercise of the state police power and an invasion of the federal foreign

${ }^{208}$ Id. at 554-55.

${ }^{209} 180$ U.S. 393 (1901). 
-relations power. In this case, a citizen of Great Britain sought to inherit real property located in California. The United States had no treaty with Great Britain on this subject, but California, by statute $^{210}$ and constitutional provision, ${ }^{211}$ expressly allowed such aliens to inherit real property in the state. The claim was made that in the absence of a treaty California had no power to permit aliens to inherit property and that the statutory and constitutional provisions in question constituted an unconstitutional invasion of the treaty power. The Supreme Court unanimously held that at least in the absence of a treaty such laws are within the competence of the police power of the states, cavalierly dismissing the foreign relations and treaty power arguments. The Court stated:

Plaintiff urges that never before has the question been directly passed upon by this court. If he means that it has never heretofore been asserted, that in the absence of any treaty whatever upon the subject, the State had no right to pass a law in regard to the inheritance of property within its borders by an alien, counsel may be correct. The absence of such a claim is not so extraordinary as is the claim itself. 212

Admittedly, there are substantial differences between this case and Holmes $v$. Jennison. ${ }^{213}$ In Holmes there was a federal policy against international extradition in the absence of a treaty, and in fact there was evidence of treaty negotiations on the subject. There was no indication of a contrary federal policy or such negotiations in Blythe. In Holmes there was a history of dealing with the matter in question by treaty, while there was no evidence of such a history in Blythe. Finally, in Holmes there was an agreement or understanding on the part of the state with a foreign government, and there was no such agreement in Blythe. Despite these differences, however, the claim of interference with the federal foreign relations power in Blythe does not seem quite as extraordinary as the Court intimated. If we are to insure equal treatment for our nationals in foreign countries, the matter of alien inheritance rights would probably be best dealt with by treaty or executive agreement, and arguably, for the states to individually allow aliens to inherit

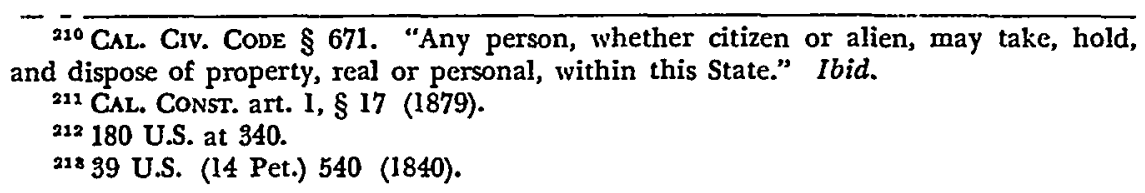


property could impair the bargaining power necessary to most advantageously secure such agreements. Moreover, to subject a matter as sensitive as the treatment of aliens to the interests of the individual states might well result in national embarrassment because of a position taken by a single state. For example, the provision of the California Constitution involved in Blythe extended greater protection to aliens of certain racial groups. The section in question read as follows:

Foreigners of the white race or of African descent, eligible to become citizens of the United States under the naturalization laws thereof, while bona fide residents of this State, shall have the same rights in respect to the acquisition, possession, enjoyment, transmission, and inheritance of property as native-born citizens. ${ }^{214}$

Apparently, it was in the parochial interest of California to exclude aliens of Chinese and Japanese descent, among other groups, from the benefits of this provision. ${ }^{215}$ One doubts that this discrimination was in the national interest.

Although these arguments demonstrate the need for national treatment of alien inheritance rights, either by exercise of the treaty power ${ }^{216}$ or otherwise, they do not necessarily indicate that California's action in this case should have been held unconstitutional. A determination to the effect that state action is an unconstitutional invasion of the foreign relations power largely depends upon a balancing of legitimate state interests against any adverse effects of the action on the nation's foreign relations. Blythe involved what appears to have been a borderline situation, with neither the state interest nor the interference with foreign relations being very substantial. In fact, the Court may have felt that any effect which the

\footnotetext{
214 CAL. CoNST. art. $1, \S 17$ (1879). As amended in 1894 and 1954 this section now reads: "Foreigners, eligible to become citizens of the United States under the naturalization laws thereof, while bona fide residents of this State, shall have the same rights in respect to the acquisition, possession, enjoyment, transmission, and inheritance of all property, other than real estate, as native born citizens; provided, that such aliens owning real estate at the time of the adoption of this amendment may remain such owners; and provided further, that the Legislature may, by statute, provide for the disposition of real estate which shall hereafter be acquired by such aliens by descent or devise."

${ }_{215}$ This discrimination was eliminated by an amendment in 1954. See note 214 supra. In any event, since CAL. Civ. CODE $\$ 671$ contains no such discriminatory classification, query whether any discrimination actually occurred, at least after 1872 when section 671 was enacted. See note 210 supra.

${ }^{216}$ Any doubt that state policies on alien inheritance rights must yield to a valid exercise of the treaty power was put to rest by Kolovrat v. Oregon, 366 U.S. 187 (1961).
} 
California provisions had on foreign relations was beneficial, since California's determination extended national treatment to British aliens rather than discriminating against them. Moreover, in the absence of any enunciated federal policy on this question, a holding that California's action was unconstitutional would have necessitated the Court's formulating a federal rule. In slightly stronger cases perhaps this would be the best way to deal with such problems, with the Court seeking the guidance of the executive branch whenever necessary in making difficult foreign relations determinations. Such an approach, broadly utilizing a federal common law of foreign relations, would achieve uniformity on foreign relations questions at the earliest possible time, and would not, of course, necessarily preclude the executive or legislative branches from later adopting a different policy with respect to a particular problem. In any event, judicial reluctance to formulate a federal rule of foreign relations is probably a factor in deciding whether there is an invasion of the foreign relations power in cases involving state action taken pursuant to the police power.

There is another point in connection with Blythe which should be mentioned. In Blythe there was no indication that California's purpose in enacting the provisions under consideration was to affect foreign relations. If there had been, it could have been strongly argued that the provisions were unconstitutional. Every applicable provision of the Constitution refutes the notion that the states can act independently for the purpose of affecting foreign relations, and it would seem that with respect to foreign affairs the Constitution at least says to the states: You may incidentally affect foreign relations in effectuating a domestic interest so long as the adverse effect of your action on foreign relations is not very serious in relation to the strength of your domestic interest, but you may not under any circumstances take independent action designed to affect foreign relations. Such a test, in addition to the balancing test already proposed, would seem to furnish a helpful constitutional standard for delineating boundaries of state competence with respect to foreign relations. Under such a test, if California had sought to regulate alien inheritance rights for the very purpose of affecting foreign relations, its action would have been an unconstitutional invasion of the foreign relations power which is exclusively vested in the federal government. This would have been the case despite the 
absence of an enunciated federal policy on the point. In this connection query whether state action discriminating between aliens on the basis of nationality in the regulation of inheritance rights would not always be unconstitutional, since there appears to be no legitimate domestic purpose which could be served by such discrimination. Perhaps, then, if the alien involved in Blythe had been a Japanese who had been denied the right to inherit, the Court's disposition of the claim of interference with the federal foreign relations power would have been different.

The Blythe case points out the obvious fact that not every exercise of the state police power which affects foreign relations is per se an unconstitutional invasion of the federal foreign relations power. Because of the primary competence of the states with respect to most domestic matters, many determinations in these areas which only incidentally affect foreign relations can best be made by the states. Determinations with respect to alien inheritance rights may even be an example, at least in the absence of unjustifiable discriminatory treatment of certain aliens or a purpose to affect foreign relations. In so cavalierly dismissing the foreign relations claim in Blythe, however, the Court failed to come to grips with the real problem, that of analyzing and balancing the state's interest in the exercise of its police power and the possible adverse effects of its action on the nation's foreign relations. Thus, the Court perhaps too broadly sanctioned state policies affecting foreign relations.

Forty-six years after the decision in Blythe, the Court was again faced with the question of California's power to regulate inheritance by aliens. Clark v. Allen ${ }^{217}$ involved the right of the Alien Property Custodian, acting on behalf of a national and resident of Germany, to inherit real and personal property located in California. The California Probate Code provided that the right of inheritance by aliens was dependent on reciprocal treatment being accorded to United States citizens in the country of which the alien was a national. ${ }^{218}$ Although the main questions considered by the Court

217331 U.S. 503 (1947).

${ }^{218} \mathrm{CAL}$. PROB. CODE $\$ 259$. "The rights of aliens not residing within the United States or its territories to take either real or personal property or the proceeds thereof in this State by succession or testamentary disposition, upon the same terms and conditions as residents and citizens of the United States is dependent in each case upon the existence of a reciprocal right upon the part of citizens of the United States to take real and personal property and the proceeds thereof upon the same terms and conditions as residents and citizens of the respective countries of which such aliens are 
were the applicability and interpretation of the 1923 Treaty of Friendship with Germany, ${ }^{219}$ it briefly considered the constitutionality of the reciprocity provision of the California Probate Code,220 since it determined that the treaty was possibly inapplicable with respect to personal property.221 Against the claim that this statute invaded the foreign relations power, the Court held without dissent that the reciprocity provision was valid in the absence of an overriding federal policy. In upholding the statute the Court once again summarily dismissed the foreign relations claim, stating that:

The court rejected the argument [in Blythe $v$. Hinckley] as being an extraordinary one. The objection to the present statute is equally far fetched.

Rights of succession to property are determined by local law. ... Those rights may be affected by an overriding federal policy, as where a treaty makes different or conflicting arrangements.... Then the state policy must give way.... What California has done will have some incidental or indirect effect in foreign countries. But that is true of many state laws which none would claim cross the forbidden line. ${ }^{222}$

To compare this statute with the state action involved in Blythe, however, is to further muddy the already murky waters. Unlike the provisions involved in the Blythe case, the major purpose of this statute was to influence foreign relations. In fact, such reciprocity statutes apparently have as their chief aims the securing of reciprocal inheritance rights for American nationals abroad and the keeping of property from foreign enemies. ${ }^{223}$ Even if on balance California

inhabitants and citizens...." Ibid. This section was enacted in 1941, and although subsequently amended, it retains the reciprocity provision. See Clark v. Allen, 331 U.S. 503, 506 n.I (1947).

${ }^{210}$ Treaty of Friendship, Commerce and Consular Rights with Germany, Dec. 8, 1923, 44 Stat. 2132 (proclaimed Oct. 14, 1925).

${ }^{220} 331$ U.S. at 516-18. Mr. Justice Rutledge felt that the Court should not have considered the constitutionality of the California statute but instead should have remanded the cause for clarification of facts necessary to determine the applicability of the 1923 Treaty of Friendship with Germany. Id. at 518 (Rutledge, J., concurring in part).

222 Id. at 514.17 .

222 Id. at 517.

${ }^{228}$ See In re Gogabashvele's Estate, 195 Cal. App. 2d 503, 523, 16 Cal. Rptr. 77, 8990 (Ct. App. 1961); In re Karban's Estate, 118 Cal. App. 2d 240, 244, 257 P.2d 649, 652 (Ct. App. 1953); Comment, State Reciprocity Statutes and the Inheritance Rights of Nonresident Aliens, 1963 DUKE L.J. 315. "Reciprocity statutes are designed to accomplish two primary goals: First, to keep money and property out of the hands of foreign enemies; and second, to induce foreign governments to grant inheritance rights to persons in this country." Id. at 317 .

The Court has on occasion looked behind the face of state action to its real purposes, 
is said to have a sufficient state interest to justify exercising its police power with respect to inheritance rights of aliens, it does not follow that California can go out of its way to exercise that power for the very purpose of affecting foreign relations. Admittedly, the California reciprocity rule will not irremedially cripple United States foreign policy, nor, in all probability, will it seriously impair the treaty power. It could at least have the effect, however, of increasing tension between our nation and others, and if it could have any adverse effect on foreign relations at all it should be unconstitutional per se in the absence of a showing of simultaneous implementation of a valid domestic interest.

Despite the broad language in Blythe and Clark, it is not clear that regulation of alien inheritance rights should ever be left to the individual states, particularly in the sense of permitting them to discriminate between aliens on the basis of nationality. In fact, there are strong reasons for suggesting that any independent state regulation of aliens as such should be unconstitutional. ${ }^{224}$ Similarly, there may be other areas traditionally within the domestic competence of the states in which state determinations might have a substantial effect on foreign relations while serving only marginal domestic interests. In any case, even though the state action in question may not be as blatant as that in Holmes $v$. Jennison, ${ }^{225}$ the courts should carefully scrutinize it to make certain that the federal foreign relations interest is not being needlessly impaired. Above all, when a state acts

particularly in the racial discrimination area. See Gomillion v. Lightfoot, 364 U.S. 339 (1960). It would seem that this should also be the case with respect to asserted state infringements on the foreign relations power.

22s The opinion of the Court in Hines v. Davidowitz, 312 U.S. 52 (1941), decided prior to Clark, contains broad language that lends some support to this suggestion. "We have already adverted to the conditions which make the treatment of aliens, in whatever state they may be located, a matter of national moment. And whether or not registration of aliens is of such a nature that the Constitution permits only of one uniform national system, it cannot be denied that the Congress might validly con. clude that such uniformity is desirable." Id. at 73. However, the present understanding-which I beheve is generally not based on a thorough evaluation of the magnitude of the problem-is largely contra to this suggestion, as is indicated by the opinions in Blythe and Clark. Sce id. at 74, 76-77 (Stone, J., dissenting); Bayitch, supra note 198, at $134-35$.

Perhaps a proper solution here in the absence of an overriding congressional or cxecutive policy would be to adopt a test akin to that used in the racial discrimination area; i.e., a state cannot take action affecting aliens as such without a showing that the classification is necessary and not mercly rationally related to a permissible state purpose. See McLaughlin v. Florida, 379 U.S. 184 (1964).

22539 U.S. (14 Pet.) 540 (1840). 
independently for the sole purpose of affecting foreign relations, such action should be held unconstitutional.

These decisions, Holmes, Blythe and Clark, are merely illustrative of some situations involving asserted state interference with the foreign relations power which have reached the courts. They demonstrate that the foreign relations power as a check on independent state action is largely regarded as merely prohibiting foreign negotiation or violation of a treaty on the part of a state and not as a check on state action pursuant to an exercise of the state police power which incidentally affects foreign relations. Moreover, the purposes for such state action have not been questioned even in situations seemingly calling for it. Since legal theories tend to be self perpetuating, perhaps given this state of the law it is not surprising that more of the numerous situations involving independent state action affecting foreign relations have not been adverted to by the courts, for lawyers, upon whom the burden of initiating judicial actions rests, tend to act in accordance with well accepted legal developments. In any event, the full potential of the foreign relations power has not yet been realized.

Lest one think that these state interferences with foreign affairs are academic or trivial, a recent Florida statute, the Florida Territorial Waters Act, ${ }^{226}$ and its subsequent application provide a prime example of the dangers of broadly sanctioning exercise of the state police power with respect to matters involving foreign relations. The act, passed in early 1963, imposed a licensing requirement which for the most part prohibits aliens from fishing commercially in Florida territorial waters. Ostensibly, it was merely a general conservation measure enacted under the Florida police power. ${ }^{227}$ As is pointed out in available biological studies, however, the migratory

${ }^{226}$ FLA. STAT. $\$ 370.21$ (1963).

${ }_{227}$ The preamble of the act states: "WHEREAs, it is the sense of the legislature to protect the vital State resources contained within the territorial waters of Florida in order to conserve the same and secure to the citizens of the State the full benefits of their patrimony. . . ." Fla. Laws 1963, ch. 63-202, at 457; 3 INT'z LEG. MAT. 289 (1964). "The entire rationale of the state conservation law (Chapter 372, [sic] Florida Statutes) is the protection of these expendable natural resources of our state. The above quoted portion of the statute [370.21(4)] clearly indicates legislative intent to exclude unlicensed alien vessels from fishing in the state's territorial waters. In view of the legal history of this particular controversy, it would appear evident that such an exercise of state police power would be well within the powers of the state and therefore completely valid." Letter from James W. Kynes, Attorney General of Florida, to Randolph Hodges, Director, Florida State Board of Conservation, Feb. 3, 1964, on file in University of Florida Law Library. 
nature of fish would probably preclude such a limited act from having any significant effect on conservation of fishery resources. ${ }^{228}$ Moreover, the act singles out nationals of Communist countries in such a fashion as to leave little doubt that the act was essentially an anti-Castro measure. Some of the more blatant provisions are as follows:

No license shall be issued by the board of conservation... to any vessel owned in whole or in part by any alien power, which subscribes to the doctrine of international communism, or any subject or national thereof, who subscribes to the doctrine of international communism, or any individual who subscribes to the doctrine of international communism, or who shall have signed a treaty of trade, friendship and alliance or a nonaggression pact with any communist power. The board shall grant or withhold said licenses where other alien vessels are involved on the basis of reciprocity and retorsion, unless the nation concerned shall be designated as a friendly ally or neutral by a formal suggestion transmitted to the governor of Florida by the secretary of state of the United States. Upon the receipt of such suggestion licenses shall be granted... without regard to reciprocity and retorsion, to vessels of such nations. 229

No crew member or master seeking bona fide political asylum shall be fined or imprisoned hereunder. ${ }^{230}$

The act authorizes fine, imprisonment and confiscation of vessels and catch for violation. 231

The act received a momentous test when, on February 2, 1964, the United States Coast Guard arrested thirty-eight Cuban fishermen and seized four Cuban vessels fishing within the three mile limit off the Dry Tortugas Islands within Florida territorial waters. The Coast Guard conducted the vessels and crews into Key West. Since the only federal law which could possibly have been applicable provided no penalties, the fishermen were subsequently turned over to state authorities for prosecution under the new act. The four captains of the Cuban vessels were tried in the Criminal Court of

${ }^{223}$ See McDougal \& Burke, The Public Order of the Oceans: A Contemporary INTERNATIONAL LAW OF THE SEA 499.520 (1962).

${ }^{220}$ FLA. STAT. $\$ 370.21$ (3) (1963).

${ }^{230}$ FLA. STAT. $\$ 370.21$ (9) (1963). The preamble of this act also provides: "WhEREAS, the Legislature intends to deny, within limitations imposed by the Constitution of the United States, to nationals of alien neutral and hostile powers the right to draw upon the resources of waters long considered by the immemorial usages of all civilized peoples a part of our State and Nation. . "Fla. Laws 1963. ch. 63-202, at 457: 3 INT'L Leg. MAT. 289 (1964).

231 FLA. STAT. § $\$ 70.21$ (8) (1963). 
Record for Monroe County, Florida. ${ }^{232}$ On conviction, they were given the maximum penalty provided by the act, a $\$ 500$ fine and a six month jail term, but the sentences were suspended on payment of the fines. The court released the vessels but confiscated their catch. As to the crew members, seven were released as minors, two sought political asylum and charges were dismissed against the remaining twenty-five on the theory that they were merely obeying orders of the captains. The convictions were obtained despite the argument, among others made on motion to quash the informations, that the Florida Territorial Waters Act was an unconstitutional invasion of the federal foreign relations power. Apparently an appeal to the Florida Supreme Court has been taken, but as of this writing no decision has been reached. ${ }^{233}$ Although there is some evidence that the United States Department of State was closely involved in the entire affair, ${ }^{234}$ at no time did the department formally intervene with Florida authorities, ${ }^{235}$ perhaps because of a desire to avoid the appearance of interfering with the states. ${ }^{236}$

\footnotetext{
${ }^{232}$ State v. Manuel Gomez Barios, Criminal Nos. 416-19, Criminal Court of Record, Monroe County, Florida, January Term 1964, 3 INT'L Leg. Mat. 317 (1964).

${ }^{233}$ Letter from James W. Kynes, Attorney General of Forida, to John Norton Moore, July 7, 1964, on file in University of Florida Law Library. Shortly before this article went to press a telephone call to the office of the Clerk of the Florida Supreme Court revealed that the convictions were recently affirmed per curiam in an as yet unpublished opinion by the Florida Supreme Court. The unanimous court gave no reasons for the affirmance, citing only Uphaus v. Wyman, 360 U.S. 72 (1959) and the opinion of the Florida Supreme Court in Gibson v. Florida Legislative Investigation Comm., 108 So. 2d 729 (1958), connected case rev'd, 372 U.S. 539 (1963). Manuel Gomez Barios v. State, No. 33,408, Fla. Sup. Ct., January Term 1965.

Since Uphaus and Gibson essentially deal with the power of the states to conduct legislative investigations into alleged subversive activities, their use as authority here would seem to reaffirm that this act is in reality more an anti-Communist than a conservation measure.

sat N.Y. Times, Feb. 6, 1964, p. 1, col. 8; Feb. 8, 1964, p. 22, col. 1; Feb. 9, 1964, p. 1, col. 8; Feb. 10, 1964, p. 2, col. 4; Feb. 11, 1964, p. 14, col. 1 .

285 "Although there was complete cooperation between State and Federal authorities at all times, the Federal Government did not intervene in the action brought in the courts of Florida and there were no formal communications between State and Federal authorities." Letter from Raymund T. Yingling, Assistant Legal Adviser, United States Department of State, to John Norton Moore, June 23, 1964, on file in University of Florida Law Library.

${ }^{23 e}$ Interestingly, Mr. Yingling suggested that I consider the constitutionality of the Florida act. "The deficiencies in Federal law concerning fishing by aliens in the territorial sea of the United States at the time the case in question arose have been remedied by the enactment of Public Law 88-308, 88th Cong., approved May 20, 1964. In view of the existence of this law, it is suggested that you might wish to consider in connection with your researcl whether there is any conflict between the laws of the State of Florida and Federal law on this question, and whether there is any constitutional question involved." Ibid.
} 
International repercussions from the incident began immediately, and the matter was taken up in the United Nations. ${ }^{237}$ It culminated in Fidel Castro directly retaliating by terminating the water supply to the United States naval base at Guantanamo.238 President Johnson counter-retaliated by curbing employment of Cuban workers at the base, ${ }^{239}$ and Senator Barry Goldwater advocated dis* patching marines to Cuba. ${ }^{240}$ Here then, is an incident of serious international significance precipitated by the independent action of a single state. Thus, it is hardly out of place to inquire whether the state statute in question unconstitutionally invades the exclusively federal foreign relations power.

Florida seeks to justify this act as an exercise of the police power intended to conserve the state's natural resources.241 Admittedly, under the state police power and in the absence of an overriding federal policy, Florida has the power to pass general measures designed to conserve resources in its territorial waters, at least with respect to its own citizens. ${ }^{242}$ To the extent that such domestic

${ }^{237}$ See N.X. Times, Feb. 3-13, 1964; U.S. Informs U.N. Security Council on Cuban Fishing Boat Incident, 50 DeP'T STATE Bull. 279 (Feb. 24, 1964).

${ }^{288}$ N.Y. Times, Feb. 7, 1964, p. 1, col. 8, p. 14, col. 5.

${ }^{289}$ N.Y. Times, Feb. 8, 1964, p. 1, col. 8.

${ }^{240}$ N.Y. Times, Feb. 7, 1964, p. 16, col. 1; Feb. 9, 1964, p. 59, col. 1.

241 See note 227 supra.

242 Skiriotes v. Florida, 313 U.S. 69 (1941). A Florida statute regulating the taking of sponges within the territorial waters of Florida was upheld as applied to one as. sumed to be a citizen of the United States and of Florida. The Court was careful, however, to point out that: "In these circumstances, no question of international law, or of the extent of the authority of the United States in its international relations, is presented." Id. at 72.

Although United States v. California, 332 U.S. 19 (1947), decided six years after Skiriotes, contains some broad language seemingly casting doubt on the Skiriotes decision, Skiriotes was adverted to and accepted by the Court. It was, however, somewhat limited. "Not only has acquisition, as it were, of the three-mile belt been accomplished by the National Government, but protection and control of it has been and is a function of national external sovereignty. . . . The belief that local interests are so predominant as constitutionally to require state dominion over lands under its land. locked navigable waters finds some argument for its support. But such can hardly be said in favor of state control over any part of the ocean or the ocean's bottom. This country, throughout its existence has stood for freedom of the seas, a principle whose breach has precipitated wars among nations. The country's adoption of the three-mile belt is by no means incompatible with its traditional insistence upon freedom of the sea, at least so long as the national Government's power to exercise control consistently with whatever international undertakings or commitments it may see fit to assume in the national interest is unencumbered." Id. at 34-35.

The power of the states to enact general conservation measures with respect to their territorial waters would seem to have been greatly strengthened by passage in 1953 of the Submerged Lands Act, 67 Stat. 29 (1953), 43 U.S.C. \$\$1301-15 (1958), which generally relinquished to the states the ownership and management of the 
measures do not seriously or needlessly interfere with foreign relations, they should be upheld against attacks based on the federal foreign relations power. It would seem, however, that the act in question goes significantly beyond the permissible limits. Aside from the very considerable question of whether this act effectuates any real conservation goal, it is by its terms not a general conservation measure but one intended to discourage foreign nationals from fishing in Florida waters. It does not apply equally to all persons who take beyond a certain quantity of fishery resources, nor does it generally regulate the taking of certain species of fish. Rather, it specifically applies only to foreign nationals. It is a conservation measure, then, only in the sense that it is designed to preserve Florida's natural resources from foreign nationals, i.e., only in the sense that it protects the state's resources against international exploitation. Protecting natural resources from international exploitation, however, should be the sole responsibility of the federal government, since it is our only government sufficiently equipped to carry out this responsibility so as to take into account the interests of the entire nation. Arguably, then, Florida's action here was taken for the purpose of affecting one aspect of our foreign relations, and this should render the act an unconstitutional invasion of the federal foreign relations power.

The act, however, would seem to be unconstitutional in this respect for more obvious reasons, since in reality it appears to be for the most part simply an anti-Castro measure. The act was not

"lands beneath navigable waters within the boundaries of the respective States, and the natural resources within such lands and waters...."

A further interesting question with respect to the Florida Territorial Waters Act presenting a situation of possible state-federal conflict arises from the fact that several coastal states, including Florida, claim state boundaries extending into territorial waters for three marine leagues, considerably in excess of the traditional three mile limit recognized by the federal government for most purposes. See Fis. Const. art. 1; United States v. Louisiana, 363 U.S. 1 (1960); United States v. Florida, 363 U.S. 121 (1960). These cases held that the Submerged Lands Act granted Texas and Florida rights in submerged lands up to three marine leagues from their coasts, since their boundaries extended that distance. Query the purposes, however, for which state control beyond the three mile limit would be valid. The situation would also seem replete with possibilities for findings that the federal government has contrary, overriding policies, particularly from attitudes of the executive department. See the remarks of Senators Russell and Bartlett in connection with the enactment of the Federal Territorial Waters Act, 109 Cong, Rec. 18498-99 (1963). See generally Bayitch, Interamerican LaW of Fisheries (1957); Garcia amador, The Exploitation and Conservation of the Resources of the SeA (2d ed. 1959); MaDougal \& Burke, op. cit. supra note 228. 
designed merely to prohibit aliens as such from fishing in Florida waters, or generally to protect Florida's resources against foreign exploitation, but seemingly its very purpose was to take politically motivated action as directly as possible against Castro's Cuba. By its terms, the act emphasizes the prohibition with respect to nationals of communist countries, absolutely denying them the privilege of fishing in Florida territorial waters, while permitting the licensing of nationals of other powers in certain cases. It is difficult to reconcile this distinction with the ostensible purpose of promoting conservation. Moreover, by exempting masters or crew members seeking political asylum, the act directly encourages foreign nationals to seek political asylum in the United States. The timing of the act further supports the conclusion that it largely serves a political purpose and is a product of the Cuban problem, for it was enacted in early $1963,{ }^{243}$ during a period of severe tension between Cuba and the United States.

The act further seems to constitute an invalid invasion of the federal foreign relations power in that it provides for the granting or withholding of licenses with respect to nationals of non-communist powers on the basis of reciprocity and authorizes retorsion. For reasons substantially the same as those discussed in considering Clark v. Allen, ${ }^{244}$ such a provision amounts to action taken for the very purpose of affecting foreign relations and thus should fall outside the permissible limits of the police power of the states. In fact, the provisions of this statute more blatantly evidence action taken for the purpose of affecting foreign relations than did the measure involved in Clark, because this statute specifically authorizes retorsion as well as reciprocity as a basis for state action, retorsion being an international law term of art used to signify retaliatory force short of war employed by one nation against another. ${ }^{245}$

Even though state action taken pursuant to the police power has as its purpose the implementation of legitimate domestic interests, such action may be in an area so intrinsically likely to involve foreign relations as to demand federal responsibility. Thus, even if the Florida Territorial Waters Act had no foreign relations purpose, arguably it would be invalid as having too great an effect on foreign

\footnotetext{
243 The act was approved by the Governor and filed in the office of the Secretary of State May 29, 1963. Fla. Laws 1963, ch. 63-292, at 459.

24 391 U.S. 503 (1947). See text accompanying notes 217-23 supra.

245 See Bishop, op. cit. supra note 200 , at 744.45.
} 
affairs relative to the domestic interest served. In any event, it should be pointed out that all of these reasons for questioning the validity of this act are applicable even in the absence of an enunciated federal policy in this area. The point is not that the provisions of the Florida Territorial Waters Act are unreasonable or even that they are not highly desirable, but simply that the states should at least be constitutionally forbidden from acting for the purpose of affecting foreign relations. Such actions, taken on the basis of the political predelictions of a single state, have so great a capacity to affect the national foreign relations interest that they must be constitutionally prohibited to the states. ${ }^{246}$

It has been assumed in this discussion that there is no enunciated federal policy respecting Florida's right to license foreign vessels fishing in its territorial waters. If there were such a policy which was inconsistent with the Florida Territorial Waters Act, Holmes, Blythe and Clark make it clear that the federal policy would control.

At the time of the passage of the act and the conviction of the four Cuban fishermen pursuant to it, the only statute which possibly could have been applicable to the situation was 46 U.S.C. section 251.247 This statute provides no penalty for fishing in United States territorial waters by foreign vessels, and it was questionable whether it even applied. That Congress even adverted to the problem of foreign vessels fishing in territorial waters when it enacted this provision is open to question. In any event, three months after the Guantanamo incident, Congress enacted a new federal measure designed to remedy the deficiencies in existing federal law pointedly illuminated by this incident. ${ }^{248}$ This measure provides for a broad prohibition against taking fishery resources from United States waters by other than United States vessels and applies stiff penalties for violation. The debates and committee reports on the act, however, largely indicate a congressional intent not to interfere with existing state laws in this area, ${ }^{249}$ and gives states directly affected a veto over

\footnotetext{
${ }^{210}$ Query also the propriety of state resolutions concerning questions of foreign affairs. See Wright, ThE CONIROL of AMERICAN Foreign RELATIONs 264-65 \& n.5 (1922).

${ }^{247}$ REv. STAT. § 4311 (1875), as amended, 46 U.S.C. § 251 (Supp. V., 1961).

24878 Stat. 194 (1964). This act, however, was under consideration by Congress before the Guantanamo incident.

260 House Comm. on Merchant Marine and Fisheries, Prohibition of Foreign Fishing Vessels in the Territorial Waters of the United States, H.R. REP. No. 1356, 88th Cong., 2d Sess. (1964); Senate Comm. on Commerce, Prohibition of Foreign Fishing Vessels
} 
any extension of fishing rights to aliens by the federal government.250 Neither of these federal statutes, then, lends much support to a contention that Congress has preempted the field of regulation of foreign vessels fishing in territorial waters. In fact, the legislative history of the 1964 measure indicates congressional approval of the role of the states in this area.

Even though these statutes may not indicate a congressional intent to preempt the field, however, it does not necessarily follow that state regulation of foreign vessels fishing in territorial waters is now constitutionally permissible because sanctioned by Congress. In the first place, the extent to which the 1964 act really sanctioned state action in this area is unclear. Moreover, the effect of congressional delegation of authority to the states in such matters is questionable. There are, of course, areas in which Congress may constitutionally authorize the states to act where they could not otherwise do so. ${ }^{251}$ If, however, an area is so intrinsically federal in nature as to require national uniformity and federal responsibility under the Constitution, Congress may be powerless to delegate responsibility to the states in that area. For example, in Knickerbocker Ice Co. v. Stewart ${ }^{252}$ the Court held that Congress may not constitutionally authorize the states to apply their workmen's compensation laws to maritime claims involving questions which demand national uniformity and federal responsibility. Mr. Justice McReynolds, writing for the Court said:

To say that because Congress could have enacted a compensation act applicable to maritime injuries, it could authorize the States to do so as they might desire, is false reasoning. Moreover, such an authorization would inevitably destroy the harmony and uniformity which the Constitution not only contemplated but actually established-it would defeat the very purpose of the grant.253

Within the Territorial Waters of the United States, S. REP. No. 500, 88th Cong., Ist Sess. (1963); Hearings Before the House Committee on Merchant Marine and Fisheries, 88th Cong., 2d Sess., ser. 88-17 (1964); Hearings Before the Merchant Marine and Fisheries Subcommittee of the Senate Committee on Commerce, 88th Cong., 1st Sess., ser. 31 (1963); 109 CoNG. REC. 18495-503 (1963).

${ }^{200} 78$ Stat. 194 (1964).

${ }^{251}$ See Prudential Ins. Co. v. Benjamin, 328 U.S. 408 (1946); In re Rahrer, 140 U.S. 545 (1891); Leisy v. Hardin, 135 U.S. 100 (1890); Forkosch, Constitutional Law 23435 (1963).

262253 U.S. 149 (1920) (5-4 decision).

${ }^{268} \mathrm{Id}$. at 164. 
Reading the Stewart opinion narrowly, Congress subsequently attempted once again to authorize application of state workmen's compensation laws in admiralty cases. ${ }^{254}$ In Washington v. W. C. Dawson \& Co., ${ }^{255}$ however, the Court reaffirmed the Stewart principle and struck down this second attempt by Congress to delegate its admiralty power to the states, basing its decision on a constitutional requirement of uniformity with respect to certain admiralty matters which Congress could not violate by delegating its responsibility to the states. Similarly, it would seem that there are foreign relations areas in which the Constitution requires national uniformity and federal responsibility, for in our relations with foreign countries the nation must speak with but one voice. Thus, neither Congress nor any other federal authority should be able to sanction independent state action with respect to matters in these areas. A strong argument can be made that regnlation of foreign vessels fishing in territorial waters is such a matter, since state action such as the Florida Territorial Waters Act provides too great an opportunity for international friction.

\section{VI}

\section{CONCLUSION}

We have strict statutes and most biting laws, The needful bits and curbs to headstrong steeds;

Which for [these] . . . years we have let sleep;

Even like an o'ergrown lion in a cave,

That goes not out to prey....

And liberty plucks justice by the nose;

The baby beats the nurse, and quite athwart

Goes all decorum. ${ }^{258}$

Although it is an often repeated aphorism that the states are constitutionally excluded from independent participation in foreign affairs, there are many hidden difficulties in implementing this standard of conduct. For the most part, the states have been cautious in pressing policies which might affect foreign relations, but nevertheless, there have been state encroachments on the federal foreign relations power, some of which constitute cause for alarm. In practice, federal supremacy in this area is not nearly as clearcut as

\footnotetext{
284 See GILMORE \& BLACK, The LAW OF ADMiralty 336-37 (1957).

255264 U.S. 219 (1924) (7-1-1 decision).

${ }^{268}$ Measure for Measure, act I, scene III.
} 
one would expect, since most of these state encroachments have simply been ignored. In the few cases of state-federal conflict that have arisen in this area, the limits of state action have been vaguely and over permissively defined.

An overhaul of most of the major problem areas with respect to state-federal participation in foreign relations is long overdue. In particular, it is time to formulate a clear rationale for a federal common law of foreign relations binding on the states and to recognize the strong constitutional justification for such a rationale. As a practical matter such a federal common law may be the only means of achieving national uniformity and federal responsibility with respect to the large number of foreign relations problems which initially arise in the courts. Insofar as Sabbatino has accomplished this objective and cleared away some of the Erie cobrvebs, there is cause for rejoicing, but Sabbatino's checkmate of the Erie confusion and constitutional difficulties in this area is alone not enough. It is also necessary that the federal common law of foreign relations be broadly conceived to avoid the hidden dangers of false domestic classification of problems that are essentially national. The state courts are not generally recalcitrant with respect to foreign relations questions, but they are unsure of the guidelines which they must follow, and, at least so far, they have too narrowly conceived the problem. In addition, thought must be given to insuring that federal review power is sufficient to compel state adherence to the federal common law of foreign relations. Even though reason would support such federal review power, the applicable statute is ambiguous in this respect and should be clarified at the earliest opportunity. Consideration should also be given to explicitly providing an initial federal forum for foreign relations questions. Under the existing fragmented approach to original jurisdiction in foreign relations cases, it is not clear that all such questions are initially cognizable in the federal courts, although this problem could perhaps be solved by simply interpreting the existing grant of "federal question" jurisdiction broadly.

Finally, and perhaps most urgently, the foreign relations power must be vitalized as an effective constitutional check on state action, joining such currently accepted rationales as interference witl interstate commerce, denial of due process, abridgement of first amend. 
ment freedoms, and denial of equal protection. ${ }^{25 T}$ This requires that constitutional guidelines with respect to the permissible limits of independent state action affecting foreign relations be sharpened. There are, of course, no bright-line distinctions between foreign and domestic affairs, but state policies must at least be scrutinized to determine if they are actually implementing legitimate domestic interests. Perhaps some state policies which definitely serve valid domestic interests must yield if their effect on foreign relations is too detrimental. Regardless of how the scales are weighted in making these decisions, however, the desirability of national uniformity and federal responsibility with respect to our foreign relations should be an ever present consideration, for in the perilous age in which we find ourselves we cannot afford to be guided by other than national or international solutions to our international problems.

${ }^{257}$ See generally Hetherington, State Economic Regulation and Substantive Due Process of Law (pts. 1 \& 2), 53 Nw. U.L. REv. 13, 226 (1958). 